MPC MAJOR RESEARCH PAPER

\title{
USE THE CGI, LUKE: ORAL AND VISUAL ELEMENTS OF NARRATIVE IN STAR WARS FILM TRAILERS
}

\author{
Marc Muschler
}

Supervisor: Richard McMaster

The Major Research Paper is submitted in partial fulfillment of the requirements for the degree of Master's of Professional Communication

Ryerson University

Toronto, Ontario, Canada

August 24, 2016 


\section{Table of Contents}

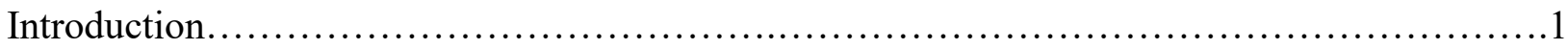

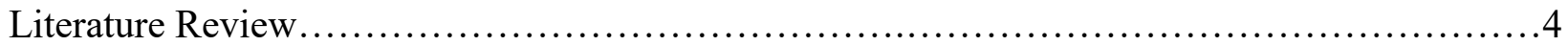

Research Questions.................................................................. 12

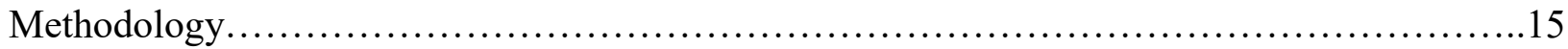

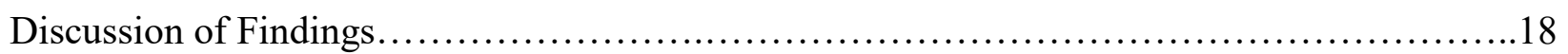

Analysis....................................................................... 42

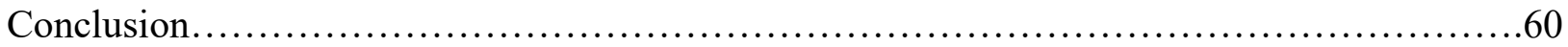

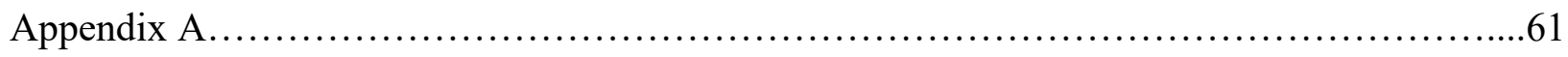

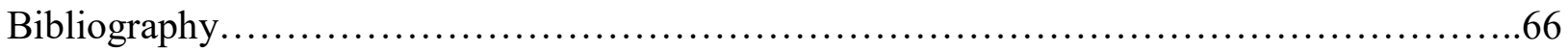




\section{INTRODUCTION}

Star Wars is one of the most successful franchises in cinematic and marketing history. Franchise revenue for the 2016 fiscal year is $\$ 3.6$ billion (Forbes, 2016), with the total of its 40-year history being much higher. From an academic and cultural perspective, it is not a stretch of the imagination to say that Star Wars is one of the most iconic brands in Western history.

At the core of this brand are the films themselves. To date, seven major motion pictures have been produced. The first, simply entitled Star Wars, was released in 1977 to great box office success. Over the course of the next 40 years, these films became part of an expansive saga taking place "a long time ago in a galaxy far, far away." The franchise's visibility in Western culture can, in some ways, be attributed to its successful marketing campaigns. In this regard, their film trailers are particularly important.

From a marketing perspective, film trailers are one of the most visible aspects of a film's marketing campaign. Over $96 \%$ of respondents to a survey regarding film trailers said they watch trailers on a regular basis (Finsterwalder et. al., 2012; 590). The advent of digital technologies has made film trailers even more widely available to the public. For instance, in 1999 over 35 million people downloaded the theatrical trailer for Star Wars, Episode I: The Phantom Menace (Bowen, 2005; 34). Better streaming services and the increased availability of the Internet has resulted in the increased popularity of viewing trailers digitally. Over 93 million people have viewed the YouTube version of the theatrical trailer for Star Wars, Episode VII: The Force Awakens (YouTube, 2016).

What makes a film trailer such a strong marketing device? Narrative may play a big role in their success. This may seem like an obvious statement; however, academic studies of 
narrative structure in film trailers are few and far between. While Kernan (2004), Maier (2009), and Gray (2010) recognize the importance of narrative as a marketing device in film trailers, very few academic sources investigate the connection between marketing and narrative in film trailers. Even fewer studies assess how film trailer narrative has developed over the course of a franchise, which is surprising given the global significance of film franchises such as Star Wars. According to an interview conducted by Chris Taylor for his book, How Star Wars Conquered the Universe, a LucasFilm spokesperson told him, "we do not know how many individual people have seen a Star Wars film in theater, but we do know that there have been approximately 1.3 billion admissions over the six films worldwide" (Taylor, 2014; 14). Such a substantial viewing audience was almost certainly influenced by the strong marketing and promotional campaigns associated with the films themselves. The purpose of this MRP is to fill the gap in existing literature by investigating the connection between narrative structure and marketing in film trailers. By assessing the narrative structure of three Star Wars theatrical trailers for three different Star Wars films (namely, Star Wars, Episode IV: A New Hope, 1977; Star Wars, Episode I: The Phantom Menace, 1999; and Star Wars, Episode VII: The Force Awakens, 2015), I hope to increase the academic understanding of the function of narrative structure in film trailers as a marketing paratext, which is understood as material surrounding an original story or concept, such as toys, books, and extended universe content in the Star Wars franchise (Gray 2010). In particular, I hope to better understand the role that oral and visual elements play in the narrative structure of film trailers.

This study will utilize a two-tiered analysis to accomplish this goal. The first step will apply William Labov's (1972) model of narrative analysis to the film trailers, and the second 
step will apply a film style analysis as outlined by Bordwell and Thompson (2012). The Labovian analysis will identify the six common features of narrative in the trailers to determine the focal points of their narrative structure, while the Bordwell and Thompson analysis will provide a supplementary analysis of key cinematic elements of the film trailers that influence the narrative. The intention behind this two-tiered approach is to provide an extensive analysis of both the oral and visual elements of narrative within the trailers. Labov's model of narrative analysis was originally intended to be used for oral narratives, and although it is useful in the analysis of film trailers, supplementing this data with information pertaining to the visual elements of trailer construction will provide a more thorough understanding of film trailer narrative. Additionally, both Kernan (2004) and Sun Jensen (2014) argue that trailers are increasingly visually-oriented to appeal more directly to audience emotions as a means of marketing a film. Therefore, this MRP's use of the Bordwell and Thompson (2012) film style analysis seeks to examine how visual elements of narrative and Labovian narrative structure supports the marketing goals of the trailers.

Overall, the goal of this MRP is to further our understanding of how marketers employ narrative in trailers to promote films, as epitomized in the Star Wars franchise.

\section{LITERATURE REVIEW}

This study seeks to understand the narrative elements employed in the film trailers of the Star Wars franchise and how their refinement over time furthers our understanding of the intersection between marketing and narrative in film trailers. This review takes into account the literature of three scholarly fields: (1) narrative analysis, (2) film studies, and (3) promotional and marketing discourse.

\section{Narrative Analysis}


Narrative analysis is a form of qualitative research that studies how stories (e.g. conversations, journals, autobiographies, etc.) are utilized by people to better understand the world around them (Lawler, 2002; 243-244). This is a fairly broad field of critical inquiry because of the extensive number of sources that can be studied within its context; however, several common methods define the field of study. Narrative analysis requires the development of a research question, answered through the organization and interpretation of selected or produced data which generally takes the form of interviews, conversations, or other forms of storytelling (Toolan, 2001). The data is sometimes interpreted through a critical lens (e.g. feminist, Marxist, etc.) that helps frame the conversation within a specific paradigm of thought. This MRP does not make use of a specific critical lens but instead focuses on a method of narrative interpretation defined by William Labov.

William Labov's work in narrative analysis is fundamental. Labov was primarily concerned with the sociolinguistics of oral storytelling and defined narrative as, "one method of recapitulating past experience by matching a verbal sequence of clauses to the sequence of events which actually occurred" (1972, 359-60). In "The Transformation of Experience in Narrative Syntax," Labov isolates and defines six recurring narrative features in face-to-face storytelling:

1. Abstract - how does it begin?

2. Orientation - who/what does it involve, and when/where?

3. Complicating action - then what happened?

4. Resolution - what finally happened?

5. Evaluation - so what?

6. Coda - what does it all mean? 
As a sociolinguist, Labov applied his narrative structure to several conversations he had with the African-American community in 1960s Harlem. Opening statements such as, "Well this person had a little too much to drink" (Labov, 1972; 360) would lead into a conversation about an argument that culminates in a physical fight, resulting in an assessment of the event that just occurred and trying to understand it within a greater social context. Breaking down hundreds of conversations into their fundamental components, Labov concluded that these six recurring narrative features can be applied in face-to-face storytelling situations universally.

Labov's method of narrative analysis is influential because of its practicality and structure. It is a model of narrative supported by the everyday discourse found in real social contexts. He identifies patterns of order that were collected from empirical evidence (i.e., numerous interviews and dialogues) as opposed to abstract theorization. This structured approach to oral narrative implies that narrative is temporally sequenced, meaning that the "original semantic interpretation" depends on the language's specific order (Labov, 1997; 21).

This strict structure has garnered criticism from academics such as Langellier, who argues that the Labovian model of narrative analysis does not account for context and audience (Langellier, 1989; 245) because it is boxed in by the six narrative elements. She suggests that Labov dismisses the influential role these factors play in narrative. De Fina (2011), notes that while the model is very descriptive, it is difficult to code and is therefore problematic from a researcher's perspective (De Fina, 2011; 35). Due to the simplicity of its six-part structure, Labov's model is also criticized for its lack of usefulness in the analysis of larger narratives such as full-length novels. It is best suited for short literary narratives or 'narratives within narratives' such as stories told by characters in a novel or play (Toolan, 2001; 167-72). Academics such as Pratt (1977) argue that Labovian narrative analysis can be applied to longer literary fiction with 
success (Pratt, 1977; 53); however, there is merit to the notion that Labov's simplistic, six narrative features are most useful in the analysis of shorter narratives.

With these criticisms in mind, several academics see a potential use for the Labovian model in the analysis of film trailers. Film trailers make little use of dialogue, and it is possible to find all six recurring narrative features in many trailers. For instance, C. D. Maier (2009) has used the Labovian model of narrative analysis to assess film trailers. She argues in her article that assessing "the verbal mode, the visual mode, and the oral mode" of 12 comedy film trailers (i.e., images, sound and music) with Labov's model highlights the persuasive purpose of film trailers by indicating the focal points of marketing intent (Maier, 2009; 161-164). This leads her to the conclusion that the shot selection process for the production of film trailers is highly strategic because marketers must visualize the value of a film narrative in a very short time (Maier, 2009; 161), resulting in a highly developed marketing paratext.

Labov's method of narrative analysis will be applied to the three Star Wars trailers under discussion and used as the theoretical framework to better understand the changes in narrative structure over the course of the franchise's 40-year history.

\section{Film Studies}

Emerging as an academic discipline in the mid-twentieth century, film studies makes use of specific critical, historical, and theoretical lenses in order to interpret film as a medium. Film studies is a broad discipline, encompassing both the humanities-centric interpretation of films as cultural objects and the technical study of filmmaking as a craft (Nelmes, 2011; xxii-xxv).

Assessing both the industry of filmmaking and the politics of film creation, the discipline allows for the interpretation of film within the context of many different fields of study. This MRP will utilize film studies (specifically, the study of the form and composition of film) as a way of 
supplementing the Labovian model of narrative analysis that has been criticized for not considering context or audience. A film style analysis provides another angle of interpretation that considers narrative from a visual perspective.

Bordwell and Thompson's (2012) text will be used to inform the film style analysis following the Labovian narrative analysis. A film style analysis is the assessment of film elements (lighting, sound, special effects) to inform a close-reading of a film (Bordwell and Thompson, 2012; 304). Hamel (2012) argues that, from a pedagogical perspective, a film style analysis can be applied to shorter cinematic works (such as film trailers) for an equally close reading of the material (Hamel, 2012; 41). Therefore, Bordwell and Thompson's method of film style analysis will be used to supplement the Labovian narrative analysis by looking specifically at several film elements that inform the visual structure of narrative. The application of both Labov and Bordwell and Thompson's theories of analysis to this MRP is detailed in the methodology section.

Many academics recognize the important role of the film trailer and narrative in marketing and promotional campaigns; however, very few book-length studies have been published on the topic. Kernan's Coming Attractions: Reading American Movie Trailers (2004) is one of the key texts in this field of study. She defines the film trailer as "a brief film text that usually displays images from a specific feature film while asserting its excellence, and that is created for the purpose of projecting in theaters to promote a film's theatrical release" (Kernan, 2004; 1-2). Kernan identifies the key marketing features of a film trailer: it is a visual tool used to convince audiences to view a film by representing its narrative as entertaining. According to the Motion Picture Association of America (MPAA), a film trailer must be less than 2 minutes and 30 seconds in length (MPAA, 2016). Therefore, marketers have only minutes to convey the 
appeal of a film's narrative to audience members. This is why the film trailer occupies a unique space in both advertising and film "wherein promotional discourse and narrative pleasure are conjoined" (Kernan, 2004, 1). Kernan's text explores the historical intertwining of promotion and narrative through the medium of film trailers, assessing the marketing and narrative elements that influence the audience's perception of a film. Analyzing hundreds of film trailers dating back to the 1920s, Kernan is considered an authority on the relationship between promotion and narrative in film trailers. Her text will be utilized in this MRP to inform the discussion of the Star Wars trailers from a historical perspective. She provides a chronological breakdown of the different styles of film trailers up to the year 2000, which is useful to understand the narrative strategies that may have influenced the creation of film trailers for the Star Wars franchise.

There are several texts relating specifically to the study of the Star Wars franchise that play an important role in contextualizing and analyzing the three film trailers being discussed in this MRP. Among these is Bowen's (2005) book, Anticipation: the real life story of Star Wars: Episode I - The Phantom Menace which details the promotion and marketing campaign before the release of the film. He provides an in-depth analysis of the release and reception of the teaser and theatrical trailers for the 1999 film from a film studies perspective. This source expands upon how critical attention and reception of the original Star Wars trilogy impacted the development of the 1999 theatrical trailer and explains the logic behind the marketing team's creative choices.

Finally, Sun Jensen’s article (2014) “Reduced narration, intensified emotion: the film trailer," explores the film trailer from a cognitive analytic perspective, assessing how its function as a promotional device impacts narrative. Her research indicates that film trailers are created by condensing a range of genre traits in order to sustain an intense emotional experience in the 
audience: "the trailer chooses to activate the main genre of the film and the corresponding range of emotions by reducing and reordering its often complex narrative" (Sun Jensen, 2014, 1). This is done deliberately by marketers to create a sustained emotional experience when viewing a trailer that will result in an audience's desire to watch the film. Her text supports the notion that a condensed narrative exists in a film trailer as an "alternative narrative" that can be broken down and assessed structurally using the Labovian method of analysis.

\section{Promotional and Marketing Discourse}

Similar to the other fields under consideration in this MRP, the study of promotional and marketing discourse is a broad field. Ranging from the study of marketing as a business tool to the interpretation of marketing as a cultural influencer, marketing and promotional discourse is varied. This MRP makes use of literature that consolidates both a humanities and businessoriented understanding of marketing within the context of film studies. Looking specifically at film and the film industry, the academic texts highlight elements of the Star Wars franchise marketing strategy which uses narrative as a marketing device.

Gray's (2010), Show Sold Separately, assesses the implications of using media paratexts as marketing devices to convey film narrative. Chapter 2, entitled "Coming Soon! Hype, Intros, and Textual Beginnings" (Gray, 2010; vii), will be particularly useful in the analysis because it specifically discusses film trailers as marketing paratexts. Using case studies such as Star Wars, Gray illustrates how narrative can be utilized as a marketing device in the promotional material surrounding a film. Informed by numerous film and marketing theorists (including Kernan 2004), he argues that narrative and narrative structure are key elements considered in the development of franchise paratexts such as film trailers. His findings reinforce this MRP's claims regarding the importance of narrative in the production of film trailers. 
Kerrigan (2009) explores the film industry as a whole and how films are marketed in an increasingly digital world. Of particular importance to this study are the two sections devoted specifically to the film trailer and her discussion of narrative as a promotional device. Her discussion comes to the same conclusions as Maier (2009), detailing the highly strategic process marketers utilize in the creation of film trailers. In particular, Kerrigan discusses how film can be visually represented and communicated to the consumer, placing a particular emphasis on the role of communication as a means of marketing to the general public and film industry. Her text supports the notion that visual communication is central to the production of film marketing and informs the discussion of how visual elements of the film trailer (computer-generated imagery/CGI, images) help define narrative structure.

Several articles relating to the marketing aspects of the film industry have been selected to supplement Kerrigan's text. These include Adams \& Lubbers (2000) and Lubbers \& Adams (2004), two articles that seek to understand the promotional and brand value of film trailers. Adams \& Lubbers (2000) explore the marketing side of promoting theatrical trailers (i.e., how film trailers are distributed) whereas their 2004 piece looks specifically at how trailers function as merchandising platforms for other marketing paratexts (e.g., toys and branded products such as cereal) that create brand awareness for major motion pictures. This includes a discussion of film trailers in franchises and the importance of "legacy marketing" for film franchises with an extensive cultural history, such as Star Wars (Lubbers \& Adams, 2004; 57). Similarly, Brown et.al.'s (2003) article assesses the importance of retro branding and the revival of brand meaning through new marketing initiatives. Although not immediately related to film or film trailers, the text discusses how to effectively market a legacy or culturally iconic brand after a promotional hiatus. These texts will be utilized for research purposes to supplement knowledge of the 
marketing of film trailers and inform the analysis of the Star Wars franchise marketing material.

Several articles that detail qualitative studies regarding the impact of film trailers on viewing audiences will be useful in contextualizing marketing intent. Jerrick's (2013) “The effectiveness of film trailers: evidence from the college student market" surveyed 154 students at the University of Wisconsin on questions relating to what makes a film trailer effective. The survey consisted of 21 questions that assessed the impact of genre, narrative framing, and other factors that influence whether or not an individual would see a film based on their initial experience with the trailer. This study concludes that previous experiences with directors, actors and actresses and the plot itself heavily influence an audience member's desire to see a film based on the trailer. A similar study was conducted by Finsterwalder, Kuppelweiser, and de Villiers (2012) that assessed consumer expectations of a film based on their viewing of a film trailer. This study was conducted with several students in which participants viewed four trailers of different genres. Like Jerrick (2013), the researchers conclude that previous experience with directors, actors and actresses and a film's setting influence an audience member's decision to see a film again. These sources provide empirical evidence that marketers would utilize in the creation of film trailers and therefore are useful to better understand the marketing intent in the creation of film trailers.

\section{$\underline{\text { Summary of Review }}$}

The literature discussed in this review will inform both the research and analysis of the three Star Wars film trailers central to this investigation. The literature review is composed of texts both directly cited in the MRP and texts used to enhance the researcher's understanding of the narrative theory, film studies, and marketing and promotion. Although the literature review does not cover the bibliography in its entirety, it provides an account of the research areas and 
literature most heavily referenced and utilized in the development of this MRP.

\section{OPPORTUNITIES FOR RESEARCH}

The review illustrates several opportunities to contribute to existing literature. In particular, there is a lack of academic material assessing the role of narrative in film trailers for the purposes of marketing. Sources such as Kernan (2004) and Maier (2009) are relied on heavily in the literature review because they are part of a small corpus which seeks to understand the power of narrative as a marketing device in film trailers. Some academics investigate film trailers as a representation of prevailing cultural values based on current events. For instance, Ivory et. al. (2007) analyzes the portrayal of violence and demographics in film trailers following the September 11, 2001 terrorist attacks. Hamel (2012), Williams (2009), Street (2009), and, to an extent, Kernan (2004), treat film trailers as visual representations of themes or tropes that dominate certain periods of cinema. There are very few studies that investigate the connection between narrative structure and marketing intent by treating the film trailer as a marketing and narrative paratext. The overarching objective of this MRP is to contribute to existing literature regarding the role of narrative in film trailers by investigating its evolving function as a promotional and communication device as epitomized in the Star Wars film trailers.

The literature regarding the intersection between film trailer narrative and promotion/marketing (in particular Finsterwalder et. al., 2012; Gray, 2010; Jerrick, 2013; Kernan, 2004; Kerrigan, 2010; Sun Jensen, 2014) focuses on the role that media paratexts (e.g., film trailers, toys, merchandise) play in the greater marketing campaign of a film or a franchise. These texts discuss the importance of film trailers in a marketing scheme and their appeal to 
audiences as a promotional device. That being said, this body of literature largely does not take into account the role of narrative structure, neglecting a major persuasive element of film trailers. This MRP will contribute to the academic understanding of how visual and oral elements influence the narrative structure and promotional/marketing strategies seen in film trailers by analyzing the relationship that exists between film trailer narrative and the oral and visual elements of the trailer. By treating film trailers as marketing devices and analyzing their narrative structure and how it is influenced by film techniques (Gray, 2010; Genette, 1997; Hedling, 2006), we can better understand how narrative functions as a marketing device within the Star Wars film trailers and how oral and visual narrative elements influence film trailer narrative.

\section{RESEARCH QUESTIONS}

A Labovian narrative analysis and film style analysis will be used to better understand how the narrative structure of film trailers is influenced by oral and visual narrative elements. This MRP looks specifically at three film trailers in the Star Wars franchise:

- $\quad$ Star Wars, Episode VI: A New Hope 1977 theatrical trailer

- $\quad$ Star Wars, Episode I: The Phantom Menace 1999 theatrical trailer

- $\quad$ Star Wars, Episode VII: The Force Awakens October 20, 2015 theatrical trailer Existing literature regards film trailers as marketing devices central to the success of a film or film franchise. Kernan (2004) and Maier (2009) have noted that a film trailer's appeal relies on the representation of the film's narrative. Marketers take advantage of the rigidity of a film trailer's structure (largely imposed by the rules and regulations established by the Motion Picture Association of American that dictate the length, time, and content of a trailer) to advertise the elements of a film to which audiences will be the most receptive. Visual and oral narrative 
elements are employed strategically within a film trailer to appeal to audiences through emotion and entertainment value. Both Kernan (2000) and Maier (2009) note that William Labov's model of narrative analysis as outlined in his article, "The Transformation of Experience in Narrative Syntax" (1972) provides six commonly recurring elements of narrative that can be applied to film trailers. Based on the successful application of Labov's model to film trailers in previous studies (most notably Maier, 2009), this study will apply Labov's model of narrative analysis- to better understand the narrative structure of film trailers within a marketing and promotional context. This study seeks to answer the following questions:

1. What visual and oral elements are employed in each of the trailers? This question reflects an interest in using Labov's six elements of storytelling to determine the narrative structure of a film trailer. Current literature (Maier, 2009) suggests that using Labov's model to identify narrative elements in film trailers can help highlight the focal points of the narrative structure central to marketing strategy.

2. Do the narrative elements change or remain the same in trailers over time? This MRP seeks to fill a gap in current literature by understanding the evolution of narrative structure in film trailers over the course of an iconic film franchise. Star Wars is iconic because it spans a 40-year period of cinema history. By using Labov's model of narrative analysis to identify film trailer focal points and a film style analysis to provide data on the visual form of the trailers, this MRP seeks to better understand how film trailer production has changed to appeal to audiences.

3. How do changes in narrative elements indicate marketing strategies? Based on the data obtained in the investigation of the two previous questions and considered in the context of current literature, this MRP will explore how this information may inform 
the academic understanding of the intersection between marketing strategy and film trailer narrative structure.

\section{METHODOLOGY}

This study is framed by narrative theory, particularly William Labov's model of narrative analysis. Based on hundreds of recorded conversations, Labov isolates and defines the following six recurring narrative features that dominate face-to-face storytelling:

1. Abstract - how does it begin?

2. Orientation - who/what does it involve, and when/where?

3. Complicating action - then what happened?

4. Resolution - what finally happened?

5. Evaluation - so what?

6. Coda - what does it all mean?

Although this narrative structure was originally produced for use in the assessment of oral narrative, it is renowned for its versatility in the analysis of narrative structures across different media. Holmes states that:

The structure identified and described by Labov and Waletzky 30 years ago is not only cited in every text concerned with narrative structure, it is also actively drawn on and used, with little if any modifications, in current work analyzing narrative structure in a very wide range of context (Holmes, 1991: 91).

Because of the widespread applicability of Labov's narrative structure that Holmes identifies, it has been applied to numerous narrative forms, including film trailers. Maier (2009) believes that Labov's structure is particularly useful in the assessment of film trailers 
"because of the narrative elements inherent in the film trailer" (Maier, 2009; 164). By applying Labov's model to the three film trailers under analysis, we can simplify these inherent narrative elements to assess their relevance as marketing and promotional devices. Both Maier (2009) and Kernan (2004) believe that the Labovian model of narrative analysis illustrates the most important sequences of shots or dialogue in a trailer that can be understood as focal points of a marketing or promotional campaign. That is, specific elements of narrative are deliberately incorporated into a film trailer in the attempt to make it an effective marketing tool. Applying Labov's model of narrative analysis allows for the dissemination of focal points of the narrative to better understand its function as a marketing device.

A film style analysis will follow the Labovian narrative analysis to assess how visual elements help construct the narrative. Considering the results of the Labovian narrative analysis along with the film style analysis will provide insight into the relationship between the narrative structure of film trailers and the film techniques used to visually represent that structure. This analysis is informed by Bordwell and Thompson's Film Art: An Introduction (2012), which provides an in-depth, step-by-step approach to the study and analysis of film. Hamel (2012) argues in his article that "it is possible to do a feature-type analysis (i.e., an in-depth analysis of a larger body of work) with a short film" (Hamel, 2012: 38) by applying the methods discussed in the Bordwell and Thompson text section entitled "Analyzing Film Style" (2012: 306-309). Bordwell and Thompson break down film and film trailer analysis into three components: (i) determine the organizational structure, (ii) identify the salient techniques used, and (iii) trace out patterns of techniques. These are very broad steps that do not provide a sufficient level of detail for the purposes of this MRP; these steps do acknowledge the importance 
of understanding film techniques in the analysis of a film trailer. This requires contextualization when assessing film trailers in order to produce a fully formed interpretation of how oral and visual narrative elements constitute the narrative structure. This MRP will assess the following film techniques in the three selected trailers in order to provide a film style analysis. These criteria have been selected based on Bordwell \& Thompson's (2012) overview of film techniques and styles that can be evaluated in a film or film trailer:

- Colouring (is specific lighting/costume design/CGI colouring used to emphasize a specific narrative motif?)

- Music/Sound (what musical score and sound effects are used?)

These two criteria were deemed particularly important elements of the narrative structure of film trailers based on an initial film style analysis that considered a wider range of film elements. This two-tiered approach to the analysis of the Star Wars theatrical trailers will provide a balanced interpretation by assessing the oral and visual elements present throughout the trailers. Doing so will provide a second level of narrative assessment to help determine the marketing strategy of the film trailers by highlighting the most important elements of narrative in the trailers.

\section{Methodological Limitations}

This study explores how oral and visual film elements are linked to and influence the narrative structure and the marketing strategy of film trailers. The study may garner criticism because the scope of the project is limited by its focus on theatrical trailers. Star Wars, Episode I: The Phantom Menace and Star Wars, Episode VII: The Force Awakens released teaser trailers before the theatrical trailer which highlights some of the narrative elements of the film. Bowen argues that teaser trailers "attempt to create interest in a movie through impressive visuals or a memorable concept" and "contains very few plot details" (Bowen, 
$2004 ; 22)$. Although there is merit in studying the narrative structure of teaser trailers, in this study it would result in an unbalanced interpretation because Star Wars, Episode VII: The Force Awakens (2015) does not have a teaser trailer to analyze. While I hope to provide a complete picture of the relationship between promotion and narrative as seen in the Star Wars film trailers, I acknowledge that limiting the scope of this study specifically to the theatrical trailers in the first installments of the Star Wars franchise trilogies limits our understanding of the Star Wars marketing strategy as a whole.

\section{DISCUSSION OF FINDINGS}

The discussion of research findings has been divided into two sections: (i) Labovian Analysis and (ii) Film Style analysis. The first section provides a summary of the Labovian narrative analysis, subdivided into the six narrative features identified by Labov and how they are represented in each film trailer. The second section is similarly divided by trailer and provides a summary of the key film style analysis observations that influence film trailer narrative.

\section{Trailer I: Star Wars, Episode IV: A New Hope (1977)}

Abstract: What was this about/How does this begin?

Labov argues that "it is not uncommon for narrators to begin with one or two clauses summarizing the whole story. When the story is heard it can be seen that the abstract does encapsulate the point of the story" (Labov, 1973; 363). Based on this definition, the abstract element can be understood as the "elevator pitch" of the narrative. The narrative is represented through one or two oral and/or visual sequences that draw the attention of the audience.

The abstract element of the 1977 trailer occurs from the start of the trailer to the 22 second mark. Within this timespan, two narrative clauses and one cinematic sequence set the 
tone of the trailer's entire narrative. The two clauses are heard as voiceover from a narrator, separated by the cinematic sequence. Both clauses are expressed through a hollow, haunting male voice with an empty backdrop of space displayed onscreen. The simplicity of the visual elements when the narrator is speaking emphasizes the importance of the narrative clauses. The first clause is: "somewhere in space, this may all be happening right now" (Star Wars, Episode IV: A New Hope theatrical trailer, 1977). In Labov's example interview, the abstract is the line, “My brother put a knife in my head" (Labov, 1972; 363). Whereas Labov’s example plainly states the subject of the upcoming story, the clause in the 1977 trailer simply indicates that events are about to occur before immediately cutting from the sparse backdrop of space onscreen to a spaceship launching and a fast-paced chase scene between two other spaceships. Leading into this visual sequence with a clause hinting at the events of the trailer, clearly establishes the action-adventure, science fiction genre of the narrative. This is followed immediately by the second narrative clause, which states: " $20^{\text {th }}$ Century Fox and George Lucas, the man who brought you American Graffiti, now bring you an adventure unlike anything on your planet. Star Wars" (Star Wars, Episode IV: A New Hope theatrical trailer, 1977). This reinforces the actionadventure, science fiction genre through the second half of the clause: "an adventure unlike anything on your planet. Star Wars" (Star Wars, Episode IV: A New Hope theatrical trailer, 1977). The first half of the clause serves the purpose of establishing the integrity of the trailer's narrative by contextualizing it within contemporary popular culture, as described in Hamel's (2012) text. Introducing the studio and the director in the orientation provides credibility to the trailer, an important step because science fiction films were not considered mainstream cinema before Star Wars was released (Kernan, 2004).

Orientation: Who does it involve and where and when? 
Labov states that "at the outset, it is necessary to identify in some way the time, place, persons, and their activity or the situation. This can be done in the course of the first several narrative clauses, but more commonly there is an orientation section composed of free clauses" (Labov, 1972; 364). The orientation element is understood as the sequence of oral and/or visual elements that define the who, what, when, and where of the narrative. It establishes the setting and key figures within the narrative.

In the 1977 trailer, the orientation can be understood as the sequence of oral and visual elements between the 23 second mark and the 44 second mark. The two major protagonists and major antagonist of the film are introduced during this element and the science fiction setting and action/adventure narrative is expanded upon. The first half of the orientation is a continuous action sequence in which the two major protagonists play a dominant role. Leia is introduced at the 23 second mark, when she exclaims "here they come!" (Star Wars, Episode IV: A New Hope theatrical trailer, 1977). This is followed immediately by an action sequence in which the spaceships seen in the abstract are engaged in space combat. During this sequence, we see Chewbacca, a secondary character whose physical appearance (i.e. he's part of an alien race) firmly establishes that the narrative takes place in a universe separate and distinct from our own. Following the space battle, the trailer cuts to Luke, who exclaims that "they're coming in too fast!" (Star Wars, Episode IV: A New Hope 1977 cinematic trailer). Although these free clauses do not advance the audience's understanding of the setting or plot, the following line delivered by the narrator, "it's a story of a boy, a girl, and a universe" (Star Wars, Episode IV: A New Hope 1977 theatrical trailer), implies that they are the boy and girl who are the subject of the trailer. The last cinematic sequence of this element reinforces those roles. In this sequence, the cloaked and masked figure of Darth Vader is seen with a menacing robot about to inject Leia 
with an unknown substance. Although not explicitly named the antagonist, his portrayal in the orientation illustrates that he is diametrically opposed to Luke and Leia.

\section{Complicating Action: then what happened?}

Labov and Waletzky define the complicating action as "the main body of narrative clauses usually comprising a series of events" (Labov \& Waletzky, 1967; 27). Labov expands on this in his 1997 paper, stating that "they provide the backbone of the story and are the most reportable event." (Labov, 1997; 404). The complicating action can then be understood as the oral and visual narrative elements that make up the bulk of a film trailer's narrative. It expands upon the orientation's introduction of the primary characters and setting of the film.

In the 1977 film trailer, the complicating action takes place between the 45 second mark and the 1 minute, 30 second mark. It is composed of a series of cinematic sequences with interspersed narration that can be understood as three distinct narrative clauses. The three narrative clauses are as follows: "It's a big, sprawling space saga of rebellion and romance;" "It's a spectacle, light years ahead of its time;" and finally "It's an epic of heroes, and villains, and aliens from a thousand worlds" (Star Wars, Episode IV: A New Hope 1977 theatrical trailer). These clauses very clearly establish the narrative of the trailer, defining it as an advertisement for an action-adventure, science fiction film. This is seen through key descriptors, such as "rebellion and romance" as well as "an epic of heroes, and villains, and aliens from a thousand worlds." Overall, the voiceover provides details of the narrative while reinforcing the science fiction elements of the trailer. The juxtaposition of these clauses with several cinematic sequences (e.g. laser battle featuring Han Solo, the verbal introduction of C3P0 and R2D2) further informs the audience by revealing more primary characters and establishing the heroes vs. villains' dichotomy central to the action-adventure narrative described by the narrator. This is seen with 
particular impact in the latter third of the complicating action, in which the voiceover assertion that the narrative constitutes "an epic of heroes" is followed immediately by a cinematic sequence involving a grappling hook, a perilous leap, and Luke and Leia kissing. Similarly, "and villains" is spoken immediately before Darth Vader interrogates and kills a prisoner. The complicating action builds on the dichotomy established during the orientation through both oral and visual elements.

Resolution: What finally happened?

Labov and Waletzky state that the resolution serves the purpose of "defining the result of the narrative" (Labov \& Waletzky, 1967; 35). Unlike the abstract, orientation, and complicating action elements, the resolution is fluid and can change places in the narrative. They state that "the resolution of the narrative is that portion of the narrative sequence that follows the evaluation. If the evaluation is the last element, the resolution section coincides with the evaluation" (Labov \& Waletzky, 1967; 35). Therefore, the resolution can be understood as a recapitulation of the final events of the story.

In the 1977 trailer, it is difficult to identify the resolution. There are no narrative clauses that coincide with this element; however, three cinematic sequences during the 1 minute, 30 seconds mark to the 1 minute, 45 seconds mark increase levels of suspense and anticipation regarding the outcome of the narrative. These cinematic sequences include Luke, Leia, Chewbacca, and Han Solo trapped in a garbage chute; R2D2 shot and taken by a Jawa; and the Millennium Falcon under the control of Darth Vader's storm troopers. Major protagonists are placed in compromising situations with no resolution provided. Ultimately, audiences are left wondering how the story will end.

Evaluation: what is the point of the narrative? 
Labov defines the evaluation of the narrative as "the means used by the narrator to indicate the point of the narrative" (Labov, 1972; 366). Essentially, the evaluation element can be understood as the "so what?" statement of the narrative. It provides a "means of registering the reportable character of events of the narrative" (Labov, 1972; 366).

In the 1977 trailer, the evaluation is found within the last ten seconds of the narrative. After the cinematic sequences and narrative clauses of the abstract, orientation, complicating action, and (partially) the resolution, the narrative concludes with the narrator stating: "Star Wars, a billion years in the making, and it's coming to your galaxy this summer" (Star Wars, Episode IV: A New Hope theatrical trailer, 1977). The voiceover is heard with the same space background onscreen as seen throughout the film trailer; however, the Star Wars logo has gradually moved forward from the abyss of space to the fore of the screen. The evaluation element plainly illustrates that the purpose of a film trailer and the point of this narrative is that viewing the film will fulfill the desire created by the trailer. The visual and oral elements of the narrative work together to effectively relay to the audience that you can resolve the narrative by seeing the film in theatres this upcoming summer.

\section{Coda: how does it all end?}

Labov and Waletzky understand the coda as an optional element present in some, but not all narratives. Described as "a functional device for returning the verbal perspective to the present moment," that is "separated from the resolution by temporal juncture" (Labov \& Waletzky, 1972; 35-37). The coda exists as a signal that the narrative has ended and brings the audience back to the point at which they entered the narrative. This often comes in the form of a generalized or iconic statement, such as "and that was that" at the end of an oral narrative (Labov \& Waletzky, 1972; 36). With this is mind, the coda of a film trailer can be considered an oral 
and/or visual statement or sequence of events that operates as a full stop to the film trailer.

In the 1977 trailer, the coda is seen in the last few seconds of the trailer, in which the Star Wars logo explodes and the blackness of space fills the screen once again. This explosion is accompanied by a loud noise reminiscent of the laser blasts heard during the orientation and complicating action elements. The ending scene of empty space and stars is the same as the opening scene at the start of the film trailer, which concludes the film trailer and returns the audience to where they entered the narrative.

\section{Trailer II: Star Wars, Episode I: The Phantom Menace (1999)}

Abstract: what was this about/how did it begin?

The abstract element of the 1999 trailer may be found at the start of the trailer to the 26second mark. This element is composed of the $20^{\text {th }}$ Century Fox and Lucas Films Ltd. logo sequence, two narrative clauses, and five cinematic sequences. The clauses are heard as character voiceover during the cinematic sequences. The characters appear in two of the cinematic sequences (both sequences take place in the same large hall and introduce the audience to the characters visually); however, their voices are initially heard prior to the characters appearing onscreen. The first narrative clause is spoken by a female protagonist, "I will not condone a course of action that will lead us to war," and the second by a male protagonist, "a communications disruption can only mean one thing, invasion" (Star Wars, Episode I: The Phantom Menace theatrical trailer, 1999). Both clauses announce that the major event of invasion and war is about to occur. This is similar to the example of an abstract narrative clause that Labov provides in his essay, which is "my brother put a knife in my head" (Labov, 1972; 363). In both instances, the statements identify a focal point of the narrative before providing a detailed account. 
The cinematic sequences in the abstract reinforce the invasion narrative identified by the character voiceovers. Immediately following the $20^{\text {th }}$ Century Fox and Lucas Film Ltd. Logos, the screen fades to black for two seconds before futuristic military vehicles rolling across vibrant, green hills appear on screen. The appearance of the vehicles establishes the science fiction setting of the trailer narrative, which is reiterated in the next visual sequence of an otherworldly, sprawling city built upon a mountain surrounded by waterfalls and lush, green forests. The female voiceover is heard during this second cinematic sequence before she is seen close-up onscreen. The male voiceover is heard several seconds later during a sequence of the previously seen tanks approaching what looks like a defensive force. The juxtaposition of the clauses with scenes of invasion position the protagonists as the victims of an unprecedented attack, further reinforcing the invasion narrative. The voiceover and cinematic sequences constitute the abstract because they draw the attention of the audience towards the central conflict of the narrative.

Similar to the second narrative clause of the 1977 trailer that contextualizes the Star Wars film within contemporary popular culture, the appearance of the $20^{\text {th }}$ Century Fox and, in particular, the Lucas Films Ltd. Logo in the abstract identifies the trailers as part of the (now iconic) Star Wars universe. As discussed in Bowen (2005), the theatrical trailer for Star Wars, Episode I: The Phantom Menace was considered the most anticipated film trailer in cinema history. Therefore, the Lucas Films Ltd. logo would be seen as an indication of the beginning of the trailer and treated with a similar level of excitement.

Orientation: who does it involve and where and when?

As Labov discusses, the orientation element establishes the setting and the key figures within the narrative (Labov, 1972; 364). Based on this definition, it is difficult to define the orientation in the 1999 trailer because characters are continually introduced throughout the 
narrative. However, the sequence of oral and visual elements between the 27-second mark and 47-second mark clearly defines the opposing sides and the roles of several major characters in the central conflict of the narrative. Three narrative clauses are interspersed among 12 cinematic sequences. These clauses illustrate that the Jedi vs. Sith conflict is central to the invasion discussed in the abstract and defines the roles of two major protagonists and two major antagonists in the overarching narrative. The first clause is spoken by the Sith, Darth Maul, to the Sith Master. He states: "at last we will reveal ourselves to the Jedi. At last we will have our revenge" (Star Wars, Episode I: The Phantom Menace theatrical trailer, 1999). This clause is spoken over the course of approximately 10 seconds of screen time, in which Darth Maul's red face, horns, and cloaked figure are visible. The cinematic sequences in which his voiceover takes place are a series of invasion-related scenes (e.g. droid soldiers marching, spaceships landing on the planet). The second antagonist, a Sith Master, is introduced following the Darth Maul sequence. He is hooded and cloaked, and simply states "begin landing your troops" (Star Wars, Episode I: The Phantom Menace theatrical trailer 1999), which is followed by scenes of droid soldiers invading the forested planet and wildlife running away from the droids. The combined effect of the visual and oral elements represents both Darth Maul and the Sith Master as the major antagonists of the film. In particular, their narrative clauses place them at the head of the invasion and in direct opposition to the Jedi. The juxtaposition of the invasion scenes with Darth Maul's voiceover gives the impression that the invasion is part of a larger plot to seek vengeance against the Jedi.

The last three seconds of the orientation introduce the major Jedi protagonists of the trailer. They appear briefly onscreen in this element and their narrative clause, "we haven't much time” (Star Wars, Episode I: The Phantom Menace theatrical trailer, 1999), positions them in 
opposition to the Sith and establishes them as defenders resisting the invasion. Although the characters appear only briefly, there is a change in tone to the trailer narrative that makes their appearance powerful. Until this point, the orchestral soundtrack in the background is reminiscent of the musical score from the original franchise. When the Jedi appear, the music stops, and so the Jedi's speech is emphasized. The change in tone also provides a full stop to the orientation before moving into the complicating action element. The representation of the Sith and Jedi plotline and its importance within the context of the overarching invasion narrative firmly establishes the "who" and "where" of the plot. Additionally, the cinematic sequences throughout the orientation reiterates the science-fiction, action-adventure genre and setting of the narrative. Complicating Action: then what happened?

Composed of oral and visual elements from the 47-second mark to the 1 minute 50 second-mark, almost half of the 1999 trailer is part of the complicating action element. Nine clauses and over 20 cinematic sequences are interspersed throughout the complicating action. The majority of clauses are delivered by or to the female protagonist introduced in the abstract, identified as the Empress of the invaded planet. The Empress's four clauses identify her as a main protagonist: "The Federation has gone too far," "Our people are dying senator, we must do something quickly," "I will sign no treaty, Senator," and "I was not elected to watch my people die while you discuss this in a committee" (Star Wars, Episode I: The Phantom Menace theatrical trailer, 1999). The urgency of the crisis becomes clear through her discussion of "dying" and that they "must do something quickly." Additionally, her role as the spokeswoman for her people becomes clear through her sense of purpose and the authority in the delivery of those lines. Her first clause, "the Federation has gone too far," identifies the Federation as the central antagonist of the narrative. This is reinforced through the cinematic sequences before and 
after the clause; the first displays two alien creatures dressed in garb similar to that of Darth Maul and the Sith Master. The second shows invading forces mobilizing on the Empress' planet. The association of the aliens with the clause and invasion sequence identifies them as members of the Federation and the perpetrators of the invasion. The Empress's last two clauses during the complicating action (namely, "I will sign no treaty, Senator," and "I was not elected to watch my people die while you discuss this in a committee") describe the bureaucracy and resistance she faces in finding support for her planet. This provides background to the dilemmas she is facing in the narrative and reiterates her role as the planet's leader.

The complicating action cements the relationship between the Empress and the Jedi, expanding on the Sith vs. Jedi dichotomy central to the narrative. The two Jedi introduced in the orientation element are seen speaking with the Empress. The leader, Qui-Gon Jinn, tells the Empress that "there is something else behind all of this. They will kill you if you stay, and I can only protect you. I can't fight a war for you" (Star Wars, Episode I: The Phantom Menace theatrical trailer, 1999). This clause indicates that the Sith are behind the invasion of the Empress' planet and that the Jedi have sided with her in order to solve the crisis. As the complicating action continues, cinematic sequences illustrate the Jedi fighting against Federation forces alongside the Empress' military which reinforces this relationship.

At the end of the complicating action several legacy characters (i.e., characters who were popularized in the original franchise) are introduced; this asserts the relationship between the original Star Wars trilogy and the 1999 trailer. C3P0, R2D2, and Yoda make appearances in the last 15 seconds of the element. There inclusion in the 1999 trailer implies a correlation between the events of this narrative and the original franchise.

Resolution: what finally happened? 
Similar to the 1977 trailer, it is difficult to identify the resolution in the 1999 trailer. There are no narrative clauses in this element; however, between the 1 minute, 50 second-mark and 2 minute, 6 second-mark, a series of cinematic sequences place major protagonists in threatening situations without revealing the outcomes, which compels the audience to resolve the narrative by seeing the film when it is released. For instance, Obi-Wan Kenobi is seen engaged in a light-saber duel with Darth Maul. Spaceships are seen fighting and exploding, a pod race takes place and a large sea creature attacks an underwater vessel containing several protagonists. Like the 1977 trailer, the part of the narrative where a Labovian resolution would typically take place is full of suspenseful sequences that offer no concrete resolution.

Evaluation: what is the point of the narrative?

The evaluation is found between the 2 minute, 7 second-mark and the 2 minute, 10 second-mark when the Star Wars, Episode I: The Phantom Menace title appears onscreen. Although there is no narrative clause in this element, the evaluation clearly demonstrates that the purpose of the film trailer is to convince the viewing audience to see the film upon its release. The gold lettering of the title accompanied by the black background provides a contrast which accentuates the title as the focal point of the evaluation. The entire trailer builds towards this climactic moment when the most obvious marketing element of the narrative appears.

\section{Coda: how does it all end?}

As mentioned previously, Labov and Waletzky considered the coda an optional element that signals the end of the narrative. In the 1977 trailer the coda took the form of an abrupt explosion; however, the 1999 trailer is considerably different in this regard. In fact, the coda operates in some ways as a second anti-resolution, offering more unresolved plot points that require seeing the film in its entirely to resolve. An anti-resolution is the opposite of a resolution; 
instead of resolving narrative points, it instead offers unresolved situations. Between the 2

minute, 10 second-mark and the 2 minute, 25 second-mark, several cinematic sequences add to the suspense and anticipation of the trailer. The Sith Master is seen stating, "wipe them out, all of them" (Star Wars, Episode I: The Phantom Menace theatrical trailer, 1999), which is followed by a close-up shot of Obi-Wan Kenobi shouting "no," followed immediately by several visuals of fighting between the Jedi and droid army and vehicles exploding. It concludes abruptly with a page of trailer credits and the phrase "The Saga Begins May 19"th" (Star Wars, Episode I: The Phantom Menace theatrical trailer, 1999). The cinematic sequences are deliberately suspenseful, implying that the Sith seek to destroy the forces of good and that something bad happens to the protagonists based on Obi-Wan Kenobi's verbal reaction. Concluding with the credits mimics the narrative style of films and brings a natural conclusion to the narrative, meaning that after credits an audience typically expects an ending. The ending phrase displayed onscreen reminds the viewing audience of the date on which they can view the film and resolve the narrative questions for themselves.

\section{Trailer III: Star Wars, The Force Awakens (2015)}

Abstract: what was this about/how does it all begin?

The abstract for the 2015 trailer takes place from the start of the trailer to the 35 secondmark. It is composed of two clauses and four cinematic sequences, concluding with the Lucas Film Ltd. logo appearing onscreen. Both clauses are expressed by female characters and relate to the protagonist introduced in the orientation. The clauses take the form of a question and answer dialogue. The first voice asks, "Who are you?" and the response from the character onscreen is "I'm no one" (Star Wars, Episode VII: The Force Awakens theatrical trailer, 2015). The audience is provided with minimal content in the abstract. Compared to the abstracts in the 1977 and 1999 
trailers, which provide at least some detail regarding the plot and narrative, the 2015 trailer is intentionally vague. This lack of information provides the audience with more questions than answers, thus drawing their attention through the mystery of the events transpiring. This strategy is reinforced by the cinematic sequences of the abstract, which are equally sparse. All of the sequences involve the female protagonist who answers the question in the abstract. She is seen scavenging through a derelict structure, walking on a desert planet with the droid, BB-8, and watching spaceships leave the same desert planet while cleaning scrap presumably gathered from her scavenging. The sparse scenes result in the audience asking the question "who are you?" themselves, drawing attention to the narrative by raising questions about the identity of the character. The scavenging, appearance of droids, and spaceships leaving the planet are all highlights of the abstract compared to the neutral background of the desert planet.

Similar to the 1977 and 1999 trailers, the appearance of the "Lucas Film Ltd." logo confirms the film as part of the Star Wars universe and orients the audience towards that narrative timeline. Its appearance onscreen is brief; however, the glittering effect of the letters juxtaposed against the black background makes it a focal point of the abstract.

Orientation: who does it involve and where and when?

The orientation takes place between the 36 second-mark and the 1 minute, 5 secondmark. It introduces the major protagonist and antagonist of the narrative and alludes to the overarching crisis of the narrative. There are two narrative clauses in the orientation: the first is spoken by Finn, who states "I was raised to do one thing, but I've got nothing to fight for" (Star Wars, Episode VII: The Force Awakens theatrical trailer, 2015). The second is said by Kylo Ren, who states, "Nothing will stand in our way - I will finish what you started" (Star Wars, Episode VII: The Force Awakens theatrical trailer, 2015). Unlike the narrative clauses in the orientation 
of the 1977 and 1999 trailers, these clauses are focused on the personal narratives of the major characters as opposed to the overarching storyline. This is supported by the cinematic sequences complementing the clauses, which suggest that the personal struggles of the major characters influence the overarching narrative. For instance, Finn's statement that he "was raised to do one thing, but I've got nothing to fight for" refers to his renunciation of his life as a storm trooper. This is illustrated through a cinematic sequence detailing his escape from a First Order spaceship and his arrival on a desert planet where he removes his uniform. The rejection of the storm trooper role establishes him as a protagonist because, in the Star Wars universe, storm troopers are typically associated with the forces of evil. This sentiment is reinforced in the first cinematic sequence of the orientation, which shows legions of storm troopers in formation in front large banners at what appears to be a rally. The imagery is reminiscent of Nazi rallies in the 1930s and 1940s [cf Leni Riefenstahl's Triumph of the Will], thus reinforcing the association between storm troopers and evil.

The representation of Kylo Ren similarly relies on previous knowledge of the franchise. Ren's clause is delivered to the destroyed helmet of Darth Vader that appears to be resting on a shrine. This scene, in combination with Ren's uniform and voice (which both reflect Darth Vader's infamous style), indicate that he is a significant figure in the First Order and therefore a major antagonist of the film. His desire to "finish what you started" implies that he wants to destroy the Republic and the Rebel Alliance, much like Darth Vader in the original trilogy. For these reasons, the orientation illustrates that the narrative strategy for the trailer as a whole relies heavily on previous knowledge of the Star Wars universe.

Complicating Action: then what happened? / Resolution: what finally happened?

The complicating action and resolution of the trailer take place between the 1 minute, 6 
second-mark and the 2 minute, 4 -second mark. The discussion of these elements has been combined because there is no clear or natural separation between the two. Both the 1977 and 1999 trailers have a point of differentiation that separates the complicating action from the resolution. For instance, in the 1977 trailer there is a shift in the subject matter of the oral and visual elements from introducing major characters and narrative focal points to positioning those same characters in suspenseful situations. No such shift occurs in the 2015 trailer; instead, the narrative introduces new characters and major plot points until the evaluation element and suspenseful cinematic scenes (e.g., major characters in torture scenes, being taken prisoner by the First Order) can be found throughout the complicating action.

The protagonists identified in the abstract and orientation (Rey and Finn) consolidate their position as the protagonists of the film with the introduction of several legacy characters. Han Solo, Chewbacca, R2D2, C3P0, and Princess Leia are all introduced in the complicating action. Their introduction coincides with the development of the overarching plotline and associates them with Rey and Finn. For instance, the first cinematic sequence of the complicating action shows the Millennium Falcon on the same desert planet on which Rey and Finn are seen. The narrative clauses in the complicating action are part of a verbal exchange between Rey, Finn, and Han Solo on the Falcon. Rey states, "there are stories about what happened" (Star Wars, Episode VII: The Force Awakens theatrical trailer, 2015), to which Han Solo replies "It's true all of it. The dark side, the Jedi, they're real" (Star Wars, Episode VII: The Force Awakens theatrical trailer, 2015). This confirms that the Force plays a central role in the trailer narrative and associates Rey and Finn with characters aligned with the side of good in the Star Wars universe. This is reiterated in several scenes in the latter half of the complicating action; Finn is seen wearing a Rebel Alliance uniform and preparing for battle alongside the Rebel military and 
he is later seen with Han Solo and Chewbacca being taken prisoner by the First Order. These scenes position the protagonists in suspenseful positions that would typically be found in the resolution element of film trailers. Similarly, Kylo Ren's position as primary antagonist is confirmed at the end of the complicating action where he is seen facing off against Finn in a light saber duel.

\section{Evaluation: what is the point of the narrative?}

The point of the narrative is to advertise for Star Wars, Episode VII: The Force Awakens. The entire narrative builds towards the appearance of the Star Wars: The Force Awakens title onscreen from the 2 minute, 3 second-mark to the 2 minute, 20 second-mark. As with the introduction of legacy characters in the trailer narrative, the evaluation makes use of similarly iconic Star Wars elements with a stark, space background and a font reminiscent of the original franchise. The transition between the complicating action/resolution and the evaluation positions the title and release date as the focal point of the narrative. After several visually intense scenes (e.g. spaceships exploding and the light saber battle between Finn and Kylo Renn) the screen goes black before the title fades onto the screen. The intense, yellow lettering of "Star Wars" dominates the screen because the subtle space background does not offer any distraction. This slowly fades until the release date of "December 19" appears onscreen, followed by the hint that "tickets are now available" for purchase.

\section{Coda: how does it all end?}

Unlike the 1977 and 1999 trailers, there is no definitive oral or visual sequences that bring the trailer to a halt. Instead, the trailer fades to black before links to several other promotional videos appear in the trailer. The 2015 trailer is the first in the Star Wars franchise designed specifically with YouTube in mind. Instead of definitively ending the narrative, the 
trailer invites viewers to explore promotional material for The Force Awakens. For instance, Lucas Films Ltd. partnered with Makers' Studios, Disney’s conglomerate of YouTube stars, to produce unboxing videos or trailer reviews relating to Star Wars content and merchandise (CNW News Group, 2015). Similar partnerships did not exist with previous film releases in the franchise. Although these options would not exist in a cinema setting, it is interesting that YouTube's video streaming services have been incorporated into the marketing strategy for the film trailer so that audiences can continue to build their excitement and anticipation for the film's release.

\section{Film Style Analysis}

As mentioned in the methodology, Labov's model of narrative analysis has been criticized for its lack of attention to context and focus on the oral elements of narrative. Due to this criticism, a brief analysis of important film style elements will supplement the analysis of the Star Wars trailers to provide context pertaining to the visual elements of the narratives.

The following analysis is based on Bordwell \& Thompson's discussion of the film style elements that can be analyzed in a film or film trailer. Although Bordwell and Thompson identify many film style elements that can be analyzed (e.g. transitions and shots), this paper focuses on the most relevant and meaningful film style elements in the Star Wars trailers: colouring/lighting and sound/music. The colouring/lighting element refers to how lighting, costume, and set colours can influence the viewer's perception of narrative. Similar to the light and dark motifs found in William Shakespeare's Romeo \& Juliet, lighting and colouring affect the audience's perception of certain characters and events. Music is similarly powerful and used in the film trailers to support certain narrative focal points. Although Labov's model of narrative 
analysis frames the discussion of the film elements, they will be discussed within the context of the film trailer instead of within the six elements themselves.

Trailer I: Star Wars, Episode IV: A New Hope (1977)

\section{Lighting/Colouring}

The colouring and lighting used in A New Hope is natural, meaning that no specific lighting tones were utilized to define the atmosphere of the film. A black and white motif dominates the costumes and settings of the trailer. This is established in the abstract, where the blackness of space and the white light of the stars are the only visual elements onscreen. This continues to develop throughout the narrative, and it becomes apparent that white is associated with the forces of good, whereas black is associated with the forces of evil. This is seen prominently in the clothing of the major protagonists and antagonists. Leia and Luke are introduced in the orientation wearing entirely white clothing, whereas Darth Vader is seen exclusively in black. Han Solo, the smuggler whose allegiances are not well-defined, is seen wearing a white tunic and black vest. With the exception of the storm troopers, this motif remains consistent throughout the film trailer. The set design reiterates this motif; whereas the Millennium Falcon is completely white, the Death Star's interior is black. This can be seen at the end of the orientation in which Leia, clad in all white, contrasts the black interior of her jail cell and the black uniforms of the Imperial officers surrounding her.

A less common motif is the dichotomy between blue and red, in which blue is associated with Jedi such as Obi-Wan Kenobi, and red is associated with Sith like Darth Vader. This can be seen in the costumes of several characters; for instance, Darth Vader, while entirely clad in black, has red embellishments on his uniform that match those of other Imperial officers. Similarly, R2D2, Obi-Wan Kenobi's droid, is white with blue embellishments. The symbolism 
behind these colours is apparent during the light saber duel between Obi-Wan Kenobi and Darth Vader in the complicating action and resolution of the narrative. In these scenes, Darth Vader's light saber is red, whereas Obi-Wan Kenobi's is blue. The lighting and colour schemes in the narrative contribute to the stark opposition between heroes and villains central to the overarching narrative by visually distinguishing between those fighting for the forces of good and those on the side of evil.

The lighting/colouring motifs impact narrative by providing a visual association with the major protagonists or antagonists of the film trailer. This helps audiences identify the heroes and villains of the narrative without having to provide oral context, an important aspect of trailer narrative development because of the limited amount of time in which a storyline can be developed and conveyed.

\section{$\underline{\text { Music/Sound }}$}

The music starts in the abstract with timid and consistent piano notes heard in the background. As the orientation and complicating action take place, the cadence escalates as scenes become increasingly action-oriented. For instance, at the end of the abstract, a new musical instrument is added to the music in the background. This occurs around the end or start of each element, with the music becoming an increasingly apparent aspect of the narrative. By the end of the evaluation, the music has become a dominating sound until the conclusive explosion sound effect of the coda. This gradual build-up increases the dramatic tension of the narrative, building towards the suspenseful moments in the resolution and the evaluation.

Sound effects are used throughout the trailer when the narrator is not speaking; laser blasts, the iconic TIE fighter space travel noises, and doors opening and closing. Because the narrative almost always occurs in space, the sound effects derive from technological elements of 
the trailer. They are louder than the music and consistent throughout the narrative; however, the number of sound effects increases as the trailer continues. For instance, the orientation is dominated by TIE fighter noises, whereas the resolution is composed of several cinematic sequences featuring a variety of sound effects. The increase in the number of sound effects indicates the building levels of suspense and tension seen in the resolution, which makes the unresolved moments of the film trailer narrative particularly poignant and memorable.

The music builds tension and suspense in the narrative, providing another emotional appeal to audiences. Sound effects have a similar effect and indicate the science fiction oral and visual effects while framing the narrative as an action-packed adventure.

\section{Trailer II: Star Wars, Episode I: The Phantom Menace (1999)}

\section{$\underline{\text { Lighting/Colouring }}$}

A blue and orange colour palette is used consistently throughout the trailer. This is consistent with action-adventure film trailers for the time, as blue and orange are considered highly energetic colours typical of the action genre (Bordwell \& Thompson, 2012). The majority of character costumes comprise varying shades of brown or beige, which emphasize the CGI elements of the film, such as light sabers and laser blasts. Unlike the 1977 trailer, there is no particular emphasis placed on white and black as visual elements of the heroes vs. villains dichotomy. Instead, blue represents good, whereas red is associated with evil. For instance, the complicating action illustrates that Jedi use blue and green light sabers, while Sith such as Darth Maul use red light sabers. This is seen in both the anti-resolution and coda, where Obi-Wan Kenobi and Darth Maul are fighting in a light saber battle. Their relatively bland clothing contrasts with the colours of their light sabers, and asserts them as focal points of the narrative. 
Additionally, Darth Maul's face is primarily red with black accents. The red provides a striking contrast with his cloaked figure and identifies him as an antagonist in the film. Laser blasts fired from Federation weaponry are also red, while laser blasts from invasion resistance fighters are blue or green. This is most apparent in the complicating action, in which invasion resistance fighters and Federation forces fight on a green field. Both sides are wearing shades of brown and beige, but the blasts from the weapons indicates their allegiance in the narrative. The dichotomy between red and blue functions in a similar capacity as the black and white motif in the 1977 trailer.

The colours indicate conflict and provide a visual confirmation of the sides on which the various characters and factions fight. They also draw attention to the action-oriented aspects of the narrative, making battle scenes particularly memorable among the numerous cinematic sequences found in the trailer.

\section{$\underline{\text { Music/Sound }}$}

Music plays a much larger role in the 1999 trailer than the 1977 trailer. The film trailer makes extensive use of iconic orchestral numbers from the original trilogy to indicate the roles and the narrative of conflict found throughout the storyline. For instance, at the start of the orientation "The Imperial March" plays when marching Federation soldiers appear onscreen. The song is associated with Darth Vader and storm troopers in the original trilogy; therefore, playing the song alongside scenes of Federation soldiers reiterates their role as the antagonists of the narrative. Music plays a similar role in establishing the Jedi as protagonists; for instance, in the orientation and complicating action "The Light Side of the Force," a song associated with Luke Skywalker in the original trilogy, plays when Obi-Wan Kenobi and Qui-Gon Jinn are onscreen. As with the other oral and visual elements of the film, the use of this legacy music relies on the 
audience's familiarity with Star Wars motifs from the original trilogy to be effective. As the narrative progresses, the musical score changes to reflect the increasing amount of conflict and action onscreen. Its intensity coincides with the increasing levels of crisis as the complicating action and resolution develops. The lack of music during the evaluation removes all oral stimuli from the narrative and emphasizes the importance of the title of the film.

Sound effects are found in abundance throughout the trailer narrative. These include blaster noises, spaceship battles and multiple explosions. Light saber noises have a particularly resonating and memorable effect because their unique sound can be heard over both music and narration in the trailer. This is seen in the resolution when Obi-Wan Kenobi is dueling with Darth Maul. Similar to the music in the trailer, sound effects gradually build towards the resolution, appealing to audiences emotionally and increasing dramatic tension. Although they are found throughout the trailer, there is a marked increase in the number and intensity of sound effects at the end of the complicating action and into the resolution. This coincides with the increasingly fast-paced appearance of cinematic sequences onscreen, which indicates the marketing intent to build the trailer narrative towards advertising the title and release date of the film.

The use of orchestral numbers and iconic music from the original franchise appeals to audiences emotionally through nostalgia and places emphasis on the roles of certain characters through their association with other iconic characters. Sound effects are similarly important in increasing the suspense and dramatic tension of the narrative, building towards the evaluation where the "so what?" of the narrative is displayed.

Trailer III: Star Wars, Episode VII: The Force Awakens (2015)

\section{Lighting/Colouring}


Similar to the 1999 trailer, the 2015 trailer makes use of a blue/orange colouring and lighting scheme. Black, white, red, and blue have similar functions as the 1977 trailer in positioning the characters on the side of good or evil. For instance, the uniforms of the First Order officers seen in the complicating action are black, as illustrated by the appearance of Kylo Ren and General Hux. Kylo Ren's visor is red, as is his light saber. This is particularly visible during his introduction in the orientation, where he is seen standing on the bridge of a ship and a large, red laser blast lights up the screen. Additionally, the laser blasts shot by First Order troops are exclusively red, which is different from both the 1977 and 1999 trailers. In contrast to this, white and blue are associated with the forces of good. When Rey is introduced in the abstract, she is wearing clothing that is entirely white, and this continues to be her colour of choice throughout the narrative. Additionally, the laser battles that take place between the First Order and the Rebel Alliance during the complicating action/resolution illustrate that the Rebels fire blue lasers and the First Order fires red, similar to those colours found in the 1999 trailer. The most obvious colour association is seen at the end of the complicating action, in which Kylo Ren and Finn face off in a light saber battle. Kylo Ren's lighsaber is a vibrant red, whereas Finn's is blue.

These colour motifs reiterate the roles of the characters as protagonists and antagonists and help identify the forces of good and the forces of evil in the narrative. Similar to other oral and visual elements of the 1999 trailer, their success relies on an audience awareness of the Star Wars universe to be effective.

$\underline{\text { Music/Sound }}$

The music in the abstract consists of echoing piano notes, but those notes fade as the orientation and complicating action/resolution take place and orchestral numbers come to 
dominate the soundtrack. This is heard in the transition between the orientation and complicating action, when the music shifts from simple notes to a full orchestra. The orchestral numbers are reminiscent of legacy music (e.g., in the complicating action a variant of "The Light Side of the Force," plays, a track used consistently through the previous six movies). The music becomes gradually louder, with heavier brass and percussion instruments dominating the seconds leading up to the evaluation when The Force Awakens title appears onscreen. Similar to both the 1977 and 1999 trailers, this increase in volume parallels the increasing dramatic tension in the narrative as action-scenes become more intense and characters find themselves in increasingly threatening situations.

In a similar fashion, sound effects gradually increase in intensity with the music, culminating in the sound of a full space battle and light saber duel in the complicating action/resolution element before the evaluation. The sound effects utilize legacy sounds (e.g. the sound of TIE fighters and X-Wings fighting) that are reminiscent of the original Star Wars trilogy.

The music and sound effects immerse the audience in an already-known universe, but the new orchestral tracks hint at the new chapter of the story that is unfolding in the film trailer narrative.

ANALYSIS

Research Question I: What narrative elements are employed in each of the trailers?

Trailer I: Star Wars, Episode IV: A New Hope (1977)

The 1977 trailer employs the abstract, orientation, complicating action, evaluation, and coda elements of the narrative effectively and in sequential order. The resolution is not present in the trailer; the omission of that section of the narrative instead furthers the marketing goals of the 
film trailer.

The narrative clauses present within the trailer demonstrate the presence of Labov's elements of narrative. For instance, the abstract, which Labov defines as one or two clauses that “encapsulate the point of the story" (Labov, 1973; 363), is very clearly articulated by the narrator within the first two clauses of the film. His statement, that "somewhere in space, this may all be happening right now" (Star Wars, Episode IV: A New Hope theatrical trailer, 1977), establishes the setting of the narrative before introducing the narrative in the second clause: " $20^{\text {th }}$ Century Fox and George Lucas, the man who brought you American Graffiti, now bring you an adventure unlike anything on your planet. Star Wars" (Star Wars, Episode IV: A New Hope theatrical trailer, 1977). The clauses frame the narrative for the audience while establishing the sciencefiction genre and action-adventure narrative. Additionally, the space setting of the abstract visually reiterates the clauses. Both the orientation and complicating action are structured along similar terms, in which the oral and visual elements of the trailer illustrate how Labov's elements of narrative are present throughout the trailers. For instance, the complicating action, considered the "backbone of the story," takes up a full third of the narrative as characters are introduced and their roles within the storyline are defined. The evaluation, typically understood as the "so what?" of the narrative, is seen with the appearance of the "Star Wars" logo onscreen, which defines the narrative's marketing intent.

The biggest difference between the 1977 trailer and the Labovian model of narrative is that the resolution is absent in the trailer. Instead of a resolution, which Labov defines as the recapitulation of the final events of a story (Labov \& Waletzky, 1967; 35), this section of the trailer is utilized to increase suspense and tension as major protagonists are placed in threatening situations. Characters such as Obi-Wan Kenobi are seen fighting Darth Vader, while Han Solo, 
Leia, Luke, and Chewbacca are seen fighting a creature in a garbage chute. These situations are left unresolved, and the evaluation element indicates that the only way to resolve the narrative is for audiences to see the full film when it is released.

\section{Trailer II: Star Wars, Episode I: The Phantom Menace (1999)}

Similar to the 1977 trailer, there is a well-defined abstract, orientation, complicating action, and evaluation within the narrative. The resolution does not exist, and instead the narrative highlights unresolved plot points that require audiences to attend the film to resolve. Unlike the 1977 trailer, the coda element plays a much more dominant role in the narrative, providing a second anti-resolution to the narrative and raising more questions for the audience.

The Labovian structure is most prominent in the first two-thirds of the trailer, in which there is a clear abstract, orientation, and complicating action. Unlike the 1977 trailer, where an omniscient narrative voice plays an important role in defining these elements, the 1999 trailer relies heavily on the interaction between oral and visual elements of the narrative. For instance, the transition between the orientation and complicating action is determined not only through narrative clauses, but through a movement in music and sound that complements the other visual and oral aspects of the narrative. Between these two elements there is an intense shift in tone heard most prominently from the movement into legacy music (e.g. "The Light Side of the Force") which reiterates the roles of different characters and factions within the narrative as new characters and plot points are introduced.

The 1999 trailer does not incorporate a resolution; instead, the narrative positions characters in compromising or threatening situations without resolving them. There is a striking similarity between the 1977 and 1999 trailers in this regard. This anti-resolution element occurs at the exact same time and place in both narratives, and the narrative is only partially resolved 
through the introduction of the film's title and release date.

The biggest point of differentiation between the 1999 trailer narrative structure and the other two trailer narratives under investigation is the coda, which is effectively a second antiresolution. Following the evaluation, the coda is composed of a series of cinematic sequences connected to the Sith Master's narrative clause, “wipe them out, all of them" and Obi-Wan's response, "no!" (Star Wars, Episode I: The Phantom Menace theatrical trailer, 1999), that is exclaimed in a voiceover that dominates the next several cinematic sequences. The scenes themselves are seemingly unrelated: The Empress, droids fighting, a boy running through a field, and two Jedi are seen in the coda. Even with the context provided in the abstract, orientation, and complicating action, it is difficult to discern the relationship between these scenes and the Sith Master's dialogue, other than to infer that all of those protagonists are at risk, and to resolve their narratives, the audience must see the film.

\section{Trailer III: Star Wars, Episode VII: The Force Awakens (2015)}

The 2015 trailer deviates significantly from Labov's narrative structure. Instead of utilizing oral and visual elements that explain the trailer's overarching narrative, as seen in the 1977 and 1999 trailers, the 2015 trailer resists these conventions and instead focuses on the personal narrative of the major protagonists and antagonists. These narratives inform the overarching storyline, but only minor details pertaining to the plot are present in the trailer. This is seen prominently in the abstract and orientation, where major characters are introduced. The complicating action and resolution also deviate from Labov's traditional model; instead, these elements are combined, providing a glimpse of the overarching narrative of the trailer while offering the same suspenseful cinematic sequences utilized in the anti-resolution elements of the 1977 and 2015 trailers. 
The abstract and orientation introduce the two major protagonists and the major antagonist of the narrative, defining them through their personal struggles. For instance, Rey, the major female protagonist, is introduced in the abstract. The verbal exchange between her and another character, in which she states that she is "no one" (Star Wars, Episode VII: The Force Awakens theatrical trailer, 2015) is juxtaposed with cinematic sequences of her solitary existence on a desolate, desert planet. Rey's lack of identity frames the trailer's narrative, implying that heroes can be found in the unlikeliest of places, an ancient and common narrative device. Finn's introduction in the orientation relates to his own personal conflict. He is first seen on a desert planet, shedding his storm trooper armour with the voiceover "I was raised to do one thing, but I've got nothing to fight for" (Star Wars, Episode VII: The Force Awakens theatrical trailer, 2015). The personal narratives of the two major protagonists feature prominently and very little context is provided that helps to develop an overarching narrative in these two elements. The importance of their personal narratives to the overarching storyline is better defined in the complicating action/resolution, but the fact that their personal narratives feature so prominently in the first half of the trailer's narrative indicates that the introduction of new characters is an important element of the narrative strategy.

As mentioned before, the complicating action/anti-resolution is combined in the 2015 trailer. There is no clear division between the two elements; instead, the complicating action continues to develop until the evaluation, whereas suspenseful or threatening situations are featured throughout the element. For instance, the complicating action opens with a space ship battle sequence in which the Millennium Falcon is in peril of being destroyed. This cinematic sequence would likely be featured in the anti-resolution of both the 1977 and 1999 trailers, but in the 2015 trailer it introduces the complicating action. Similarly, the complicating action/anti- 
resolution ends with Kylo Ren and Finn facing off in the light saber duel with no clear winner. This is similar to the anti-resolution cinematic sequences found in the other two trailer narratives. It plays a major role in developing Finn's character because it positions him in direct opposition to the First Order for the second time in the narrative.

$\underline{\text { Summary of Observations }}$

Overall, the most striking similarity between all of the trailers is the treatment of the antiresolution and evaluation elements of the narrative. All three trailers reject Labov's resolution element in favour of cinematic sequences that increase suspense by placing major protagonists in threatening situations. They leave these plot points unresolved, instead suggesting in the evaluation that the audience must view the entire film upon its release to resolve the narrative. Labov's model of narrative analysis clearly indicates that this is part of the marketing intent of film trailers---the abstract, orientation, and complicating action of the three trailers---introduce the major protagonists, antagonists and storylines, while the anti-resolution incentivizes the audience to see the film to resolve those same narratives.

The coda differs significantly between the three trailers. It is used in a range of ways: the 1977 trailer simply uses the sound and visual effect of an explosion to signal the end, the 1999 trailer utilizes it as a second anti-resolution where more questions are posed to the audience, and the coda is entirely absent from the 2015 trailer. These differences illustrate the flexibility of the film trailer as a medium of narrative. Although they are all telling a story involving an actionadventure story in the science-fiction genre of the same universe, the trailer narrative can be utilized in different ways to convey a similar marketing message.

Research Question II: Do the narrative elements change or remain the same over time? 
Changes in the trailer's narrative elements reflect and conform to the conventions of film trailers at the time of their production. This is particularly true regarding the balance between oral and visual elements. Cinematic sequences in the later trailers dominate storytelling, while narration (e.g. the omniscient narration of the 1977 trailer) becomes less important than it was in the earliest trailer's structure.

\section{$\underline{\text { Abstract }}$}

The abstract of the three trailers clearly demonstrates how the norms of trailer narrative structure have changed over time. Although structurally they convey a similar message (i.e. establishing the setting and introducing the narrative), the changes in the abstracts indicate a movement towards more visually-oriented storytelling techniques.

For instance, the 1977 trailer has a strong omniscient narrative voice starting in the abstract, whereas both the 1999 and 2015 trailers rely on character voiceover and dialogue to introduce the narrative. Clauses in the 1977 trailer such as "somewhere in space, this may all be happening right now" (Star Wars, Episode IV: A New Hope theatrical trailer, 1977) are different from the exchanges and voiceover heard in the 1999 and 2015 trailers. According to Kernan (2000), the 1977 trailer is typical of The Contemporary Era of film promotion, in which corporate, marketing-driven regimes were central to the creation of film trailers (Kernan, 2000; 164-167). This remains true in the creation of film trailers; however, over the course of 40 years, trailer creators have experimented with other forms of narrative structure that appeal to audiences. Contemporary Era trailers were highly formulaic, relying on "the rhetoric of genre privilege" (Kernan, 2000; 165) typical of the classical era of trailer creation. As trailers became more popular globally, it was assumed that many audiences (instead of purely Western ones) would see a film's trailer (Kernan, 2000; 165). Therefore, trailers became highly structured (and 
universally appealing) marketing devices that used an omniscient narrator to explicitly shape the audience's opinion of the film. The abstract of the 1977 trailer is similar to those of other major action-adventure blockbusters of the time, such as Jaws (1975).

The 1999 trailer's abstract is composed of a conversation between the Empress and her advisor that informs the audience of the major storyline of invasion. This conversation is supplemented by cinematic sequences that make it clear that her world is being invaded by a droid army. Unlike the 1977 trailer where the visual elements of the abstract consist of the background image of space, the 1999 trailer utilizes vibrant cinematic sequences (e.g. CGI armies) to reiterate the sense of urgency felt by the Empress and highlight the science-fiction setting. The 2015 trailer's abstract follows this pattern as well; dialogue and voiceover are used sparsely and do not provide any information about the overarching narrative. The 1977 and 1999 abstracts establish the setting and hint at the narrative of the trailer, but the one exchange between Rey and another female voice in the 2015 trailer only highlights Rey's uncertainty about herself. Meanwhile, cinematic sequences reiterate this uncertainty by illustrating her lifestyle as a scavenger on a desolate desert planet. The distinction between the narrative focus of the abstracts indicates the different types of stories being told in the film trailers. For instance, the focus on Rey's personal narrative demonstrates that the film trailer narrative is much more characterdriven than the 1999 trailer, which is primarily concerned with the overarching storyline of the invasion of Naboo and the Sith vs. Jedi. Although all of the trailers are science fiction and action-adventure oriented, their focus is very different.

\section{$\underline{\text { Orientation }}$}

The orientation has a similar function to the abstract; it introduces more characters to the narrative and is supposed to provide the "where and when" of the overarching storyline. 
Although all three films use visual elements in abundance in the orientation, there is a marked movement away from narration towards more informal, dialogue-based oral elements in the later trailers. For instance, the 1977 orientation has a few instances of characters speaking; however, these verbal elements would be considered free clauses (Labov, 1972; 360), which is dialogue that does not influence the narrative. Leia exclaims "they're coming in too fast!" (Star Wars, Episode IV: A New Hope theatrical trailer, 1977) in reference to the space battle taking place in the orientation. The narrator's clauses are primarily responsible for highlighting fundamental components of the plot (e.g. "The story of a boy, a girl, and a universe"). The dialogue in the orientation of the 1999 and 2015 trailers is much more narrative-focused and drives the audience's understanding of the storyline. For instance, in the 1999 trailer's orientation, Darth Maul states to the Sith Master, "at last we will reveal ourselves to the Jedi. At last we will have our revenge" (Star Wars, Episode I: The Phantom Menace theatrical trailer, 1999). This dialogue, understood in the context of the cinematic sequences of the orientation, provides insight into the Sith's role in the invasion of Naboo (i.e. the Empress' planet) and the motivation behind that invasion. Kylo Ren performs a similar role in the orientation of the 2015 trailer. During his introduction, he states "nothing will stand in our way. I will finish what you started" (Star Wars, Episode VII: The Force Awakens theatrical trailer, 2015), while talking to the destroyed helmet of Darth Vader. This sequence illustrates that he is a major antagonist in the film and implies that the overarching narrative of the trailer involves Darth Vader's plans for a galactic empire.

The use of narrative dialogue instead of a narrator is part of the movement away from classical trailer narrative structure to a focus on the visual elements of the film. The dialogue of both Darth Maul and Kylo Ren must be considered within the context of the cinematic sequences 
in which they take place. This is in contrast to the narrator's voiceover of the 1977 trailer which is only heard when the space backdrop is the dominating visual element onscreen.

\section{Complicating Action}

The complicating action constitutes one-third to one half of each trailer, making it a particularly prominent element of the narrative in all three trailers. This element demonstrates the most significant change in narrative strategy between the three trailers. Visual elements become a dominant feature of narrative expression while the importance of narrative voiceover decreases. The complicating action demonstrates how the 1999 and 2015 trailers rely on legacy characters and film elements (e.g. music and colouring) in the construction of the narrative. The trailers utilize different aspects of the original franchise's cultural popularity to reinforce protagonist and antagonist roles and to support the overarching narrative of the trailer.

This is first seen in the 1999 trailer, where the complicating action is composed of 20 individual cinematic sequences. This contrasts with the 1977 trailer, in which less than a third of that number of sequences occur. Although only 15 seconds longer than the 1977 trailer's complicating action, the element in the 1999 trailer is much faster-paced. For instance, the cinematic sequences in the 1999 trailer last on average anywhere between 2-3 seconds, whereas the sequences in the 1977 trailer's complicating action are, on average, over twice as long. A similar pattern is seen in the 2015 trailer; although not as fast-paced as the 1999 trailer, the latest trailer presents significantly more cinematic sequences in the complicating action than the 1977 trailer. The content of the cinematic sequences is different as well. For instance, one of the most action-packed sequences of the 1977 trailer's complicating action is the laser battle between Han Solo and storm troopers outside of the Millennium Falcon. This sequence takes a full six seconds, in which Han Solo is seen running around the Millennium Falcon while storm troopers 
shoot at him. Action sequences in both the 1999 and 2015 trailer's complicating actions are about one third of the same length. Instead of showing protagonists engaged in combat, action sequences are typically composed of 1-2 seconds of explosions or ships fighting other ships. These sequences provide a great amount of detail about the film trailer's storyline, offering a number of minor but insightful glimpses into the progression of the narrative.

The complicating action of the 1999 and 2015 trailers also demonstrates the increased reliance on iconic characters and franchise motifs to appeal emotionally to audiences. Legacy characters such as Yoda, Han Solo, Leia, C3P0, and R2D2 feature prominently in this element in both trailers, reminding audiences of the original franchise and offering a sense of nostalgia to the viewing audience. Similarly, iconic orchestral scores from the original franchise play a prominent role in the 1999 and 2015 complicating actions. Both "The Imperial March" and "The Light Side of the Force" are heard in the complicating action of the 1999 trailer. These musical scores help audiences determine the role of protagonists and antagonists within the overarching narrative. For instance, "The Imperial March" plays when Darth Maul appears onscreen in the 1999 trailer. The song is associated with Darth Vader in both the films and popular culture; therefore, it can be assumed that Darth Maul is similarly antagonistic in the 1999 trailer's narrative. In the 2015 trailer, a variant of the score "The Light Side of the Force" can be heard in the complicating action when the Millennium Falcon is onscreen, thus associating it (and its passengers) with the forces of good in the narrative.

Overall, the complicating action of the three trailers serves to demonstrate how visual elements become increasingly important to the development of narrative strategies for film trailers. They also illustrate that iconic characters and music are used effectively in this element to help audiences better understand the roles of new characters in the overarching Star Wars 
narrative.

$\underline{\text { Resolution }}$

All three trailers do not have a resolution. Instead, the narratives incorporate an antiresolution element, in which major protagonists are placed in threatening situations that are left unresolved. This element increases levels of tension and anticipation near the end of the trailer, incentivizing the audience to see the entire film, that is, the product being marketed, when it is released to discover how these narrative conflicts are resolved. Both the 1977 and 1999 trailers make use of this element before the evaluation. The 2015 trailer does not do this; instead, the complicating action and anti-resolution are combined and cinematic sequences typically associated with the anti-resolution element can be found anywhere between the orientation and evaluation.

For instance, the resolution in the 1977 trailer takes place within a 15 second timespan. During this brief span, cinematic sequences place protagonists in threatening situations: Luke, Leia, Chewbacca, and Han Solo are trapped in a garbage chute, R2D2 is shot and taken by a Jawa, and the Millennium Falcon is placed under the control of Darth Vader's storm troopers. Similarly, the resolution of the 1999 trailer is 16 seconds long and similar events occur: Obi-Wan Kenobi is seen engaged in a light saber duel with Darth Maul and a large sea creature attacks an underwater vessel containing several protagonists. In each situation, the fate of the protagonists is not certain and the narrative goes unresolved.

Interestingly, this element shows the least amount of development in the film trailers, meaning that cinematic sequences associated with the anti-resolution are similar throughout all three trailers. For instance, each trailer features an unresolved light saber duel right before the evaluation. In the 1977 trailer it is between Obi-Wan Kenobi and Darth Vader, the 1999 trailer 
features Obi-Wan Kenobi and Darth Maul, and the 2015 trailer shows Kylo Ren and Finn preparing to fight. These sequences are the most significant representations of the heroes vs. villains dichotomy that dominates the trailer.

$\underline{\text { Evaluation }}$

The evaluation element is essentially the same in all three trailers and demonstrates the marketing intent behind the trailer's narrative. In each trailer, the evaluation element is composed of a black background and the appearance of the title of the film. These titles are of similar size and font and appear onscreen for almost the exact same amount of time. The only significant difference is that the 2015 trailer utilizes a font type reminiscent of the original trilogy, whereas the 1999 trailer has a font unique to the three films of that trilogy.

The lack of development in the evaluation element of the three trailers over the course of a 40-year period indicates the marketing intent behind the trailer narratives. The evaluation element is the "so what?" component of trailer and indicates the point of the narrative (Labov, 1972; 366). Therefore, the trailers show that the point of a film trailer narrative is to advertise the title and release date of the film (Kernan, 2000; 4).

Coda

The coda takes on different forms throughout the three trailers but is of little consequence to the overarching narrative strategy. The 1977 film trailer's coda is the large explosion that concludes the narrative; this operates as a full stop to the film trailer and returns audiences to their point of entry to the narrative, namely, the blank space background that they were introduced to in the abstract. The 1999 trailer's coda operates as a second anti-resolution, raising more questions about the unresolved narratives of the major protagonists before fading to black. Audiences are provided with more content regarding the Sith's desire to kill the protagonists of 
the film. The cinematic sequences in the coda (e.g. Obi-Wan Kenobi shouting, "no!') are a second chance for audiences to be reminded of the unresolved plot points that will be featured in the film itself. The 2015 trailer simply ends by fading to black, although the YouTube version of the trailer offers the ability to view other promotional content for the film. Ultimately, these variations in the coda demonstrate how it is used effectively to both end the trailer and raise additional questions regarding the narrative of the trailer itself.

\section{Question III - How do changes in narrative elements in film trailers indicate marketing} strategies?

The changes in narrative strategy over the course of the 1977, 1999, and 2015 Star Wars trailers reflect an interest in emphasizing visual elements in the narrative of the film trailer to appeal to audiences emotionally. This movement towards more visually-impactful trailer narratives conforms with academic research relating to the relationship between audience perception and film trailer success. Sun Jensen (2014) argues that the trailer creates an "emotional, monomaniac version of the film" (Sun Jensen, 2014; 123) by developing a narrative that relies evokes audience emotion through visual stimuli. The increase in speed, volume, and intensity of the cinematic sequences in the 1999 and 2015 trailers likely relate to this emotional appeal through suspense and dramatic tension.

Both Bowen (2005) and Taylor (2015) argue that Star Wars marketers recognize the importance of emerging technologies such as CGI in the 1990s and incorporate this technology into the narrative structure of the 1999 trailer. For instance, one of the biggest developments between the 1999 and 2015 trailers is the increase in cinematic sequences in the complicating action. There are more than three times the number of cinematic sequences in the 1999 film 
trailer compared to the 1977 trailer, even though it is only 15 seconds longer. Whereas the 1977 trailer's complicating action makes use of longer visual sequences featuring major protagonists to express the action-adventure aspects of the narrative (e.g. Han Solo's fight with the storm troopers), the 1999 trailer utilizes fast-paced action scenes in quick succession. These sequences feature explosions and laser battles of an intensity not seen in the 1977 trailer. This reflects Sun Jensen's conclusion that genre is prioritized as the focal point of the film trailer narrative (Sun Jensen, 2014; 123) by placing elements of the action-adventure narrative at the forefront of the trailer. Scenes depicting action-adventure elements feature more prominently so that marketers can take advantage of the intersection between the genre and feelings of excitement to appeal to audiences through their emotional engagement with the film.

The change in narration patterns over the three trailers demonstrates the marketing desire to increase audience engagement through emotional stimuli. The 1977 trailer utilizes an omniscient narrative voice that explains the trailer narrative while not actively participating in it. For instance, one of the definitive lines of the complicating action is "the story of a boy, a girl, and a universe" (Star Wars, Episode IV: A New Hope theatrical trailer, 1977). This line, as with all of the narrator's lines, occurs when a scene of black space is onscreen. The clause itself advances the narrative; however, it is not something that a character would say within the context of the narrative. Audience members understand the basic tenets of the narrative (e.g. it's about a boy and girl saving the universe from an evil antagonist) without engaging with the characters. This changes in the 1999 trailer, in which the characters of the film provide the dialogue. For instance, the abstract's oral elements are provided entirely by a voiceover conversation between the Empress and an advisor who discuss the invasion occurring on their planet. The 2015 trailer reflects a similar narrative style, in which character voiceover is the primary method of narration. 
This is seen in the orientation's narrative clauses, which are spoken by Finn and Kylo Ren, the major protagonist and antagonist of the trailer's narrative. The omniscient narrator of the 1977 trailer provides a buffer between the audience's engagement with the narrative's characters. The major characters' active participation in the narrative means that their dialogue is more engaged in the narrative compared to that of an omniscient narrator. Therefore, they provide a greater sense of the urgency and dramatic tension than the 1977 narrator.

The use of legacy characters, music, and motifs in the 1999 and 2015 trailers is another development in narrative that reflects marketing strategy. According to qualitative research conducted by Finsterwälder et. al. (2013) and Jerrick (2013), audience members respond better to trailers in which they are familiar with the characters and certain visual and oral elements. Because both the 1999 and 2015 trailers rely heavily on the performances of relatively unknown actors and actresses, legacy characters such as Han Solo, R2D2, Princess Leia, and C3P0 are referenced frequently to appeal to the audience's nostalgic sense of connection to the narrative. This is seen in the complicating action of the 2015 trailer, in which several major characters from the original franchise are introduced and play a significant role in the trailer's narrative. For instance, the appearance of the Millennium Falcon and Han Solo initiates the complicating action, and his conversation with Rey provides the oral elements of narrative for the entire element. He states, "It's true, all of it. The dark side, the Jedi, they're real" (Star Wars, Episode VII: The Force Awakens theatrical trailer, 2015). This statement confirms that the Sith vs. Jedi dichotomy is central to the trailer's narrative but reminds audiences history of the Star Wars narrative as a whole. This line, delivered by Han Solo who infamously did not believe in the Force throughout the majority of the original trilogy, will resonate with audience members familiar with this history. 
The film style analysis illustrates that colour motifs and iconic music/sound effects play an important role in the 1977,1999 and 2015 trailer narratives. In particular, the association between the Sith with red and black and the Jedi with blue and white permeates the entire 40year history of the franchise. This provides audiences with a point of reference that allows them to experience the narratives within a historical context. In other words, audiences who have prior knowledge or experience with the Star Wars franchise are provided with visual points of reference that allow them to understand elements of the film trailer narrative without oral elucidation. For instance, the light saber battle between Obi-Wan Kenobi and Darth Vader in the anti-resolution of the 1977 trailer indicates that red light sabers are used by Sith and blue light sabers are used by Jedi. Similarly, the uniforms of Darth Vader and Imperial officers are completely black, as are the interiors of the spacecraft seen in the narrative (e.g. Princess Leia's cell aboard the Death Star). This colour motif is found in both the 1999 and 2015 trailers, where red and black denote similar connotations. Darth Maul, the primary antagonist of the 1999 trailer, wears only black and his face is almost completely red. His light saber (as seen in the anti-resolution and coda) is red as well. The 2015 trailer similarly uses red and black in the uniform and light saber of Kylo Ren. His uniform is completely black and his introductory scene in the orientation is heavily coloured by the red beam of light in the cinematic sequence. His light saber is also red, as seen immediately before the evaluation in his standoff with Finn. Audiences familiar with the franchise recognize these colour motifs in the narrative. These colour motifs operate as points of reference; audiences will understand the connotations of a red or blue light saber or a black uniform without having to be informed of their importance. Ultimately, the colour motifs reinforce the role of major protagonists and antagonists through their association with the Jedi or the Sith. Similar to the legacy characters, this motif appeals to 
audience members who understand the association and it allows them more actively engage with the narrative.

Music and sound effects play a similarly important role in engaging audience members. Both the 1999 and 2015 trailers make use of orchestral scores and sound effects reminiscent of the original franchise. For instance, the 1999 trailer's complicating action has two iconic scores from the original trilogy: "The Imperial March" and "The Light Side of the Force" (Star Wars, Episode I: The Phantom Menace theatrical trailer, 1999). The first score, typically associated with Darth Vader, is played during the initial appearance of Darth Maul. This reiterates the connection between Darth Maul and the dark side of the Force. Similarly, "The Light Side of the Force" plays when Obi-Wan Kenobi and Qui-Gon Jinn are onscreen, reiterating their connection to the Jedi Order. Similarly, "The Light Side of the Force" is heard in the 2015 trailer's complicating action with the appearance of the Millennium Falcon. Similar to the legacy characters and colour motifs, the music reiterates the role of the protagonist and antagonist in the overarching narrative by appealing to the audience's previous knowledge and experiences with the Star Wars universe. This type of marketing strategy reflects the research previously noted, providing emotional appeals to audience members to engage them in the film trailer's narrative and entice them into seeing the film itself.

Overall, an analysis of the developments in oral and visual elements of film trailers in the Star Wars franchise indicates that visuals play an increasingly important role in the expression of narrative, and that limiting narration to character dialogue promotes a greater emotional connection between the audience and trailer narrative. Additionally, marketers rely heavily on legacy characters, music, and motifs in order to reinforce the roles of newly introduced characters and appeal to an audience's previous knowledge of the Star Wars universe to increase 
engagement.

\section{Suggestions for Further Study}

Findings in this study are not representative of all film trailers or franchises though there may be broad similarities in film trailers from similar eras. The intention of the analysis undertaken in this MRP is to demonstrate how changes in the oral and visual elements of a film trailer's narrative structure help determine marketing strategy over the course of a franchise. This study aims to promote broader academic investigation of the role film trailers play as marketing and promotional paratexts. Future studies can expand upon this work in the following areas:

1. Intermediality: Quantitative and qualitative studies about audience engagement with film trailers would be useful to determine the future of the film trailer as a marketing device. Jerrick (2013) and Johnston (2008) have done research into the topic. However, the relationship between the changing intermedial role of the film trailer and how this will impact trailer narrative has yet to be investigated.

2. Film Trailers as a Microcosm of Corporate Marketing: The Star Wars franchise is one of the most heavily marketed narratives in history. Merchandising expands beyond the films and into toys, food, theme parks, and numerous other paratexts. Understanding the narrative structure of film trailers within the context of this greater marketing initiative would provide some useful and interesting data regarding the relationships that exist between marketing paratexts. Gray (2010) discusses this to some extent in his text, but the recent acquisition of the franchise by The Walt Disney Corporation and the new franchise undertakings would allow for even more extensive study.

3. Expanded Study: This MRP was limited to three film trailers to limit the data set to a manageable amount. However, there is room to expand this study and assess the role of 
narrative in Star Wars marketing paratexts as a whole. In particular, this study could be expanded to include all Star Wars trailers for a more thorough understanding of how narrative serves marketing interests in the franchise's promotional material.

\section{CONCLUSION}

This MRP explores the relationship between narrative structure and oral and visual narration strategies as illustrated in three Star Wars theatrical trailers. The theatrical trailers for Star Wars, Episode IV: A New Hope (1977), Star Wars, Episode I: The Phantom Menace (1999), and Star Wars, Episode VII: The Force Awakens (2015) provide an overview of the development of narrative structure strategies utilized throughout the franchise's forty-year history. By applying William Labov's theory of narrative analysis (1972) and Bordwell and Thompson's film style analysis (2012) to the three trailers, this MRP demonstrates that marketers are increasingly attempting to elicit an emotional reaction and connection from audience members through the use of visually compelling narratives that rely on suspense and an awareness of the Star Wars brand in popular culture. This study additionally illustrates that Labov's model of narrative analysis is useful in the interpretation of film trailers because it can be used to identify patterns of narrative structure which can help illuminate the narrative intent behind marketing strategy. In a broader context, this study is useful in understanding how narrative structures function in film trailers, a relatively understudied marketing paratext that is increasingly important in film marketing and promotional strategies.

\section{Appendix A: Labovian Narrative Analysis}

Star Wars, Episode IV: A New Hope (1977)

Narrative Element
Observations 


\begin{tabular}{|c|c|}
\hline Abstract & $\begin{array}{l}\text { - Narrator: "somewhere in space, this may all be happening right } \\
\text { now." } \\
\text { - Opening scene is space background with something } \\
\text { undiscernible in the distance approaching the screen. You can } \\
\text { only hear the narrator } \\
\text { - Opening frame of escape pod and Millennium Falcon chasing } \\
\text { TIE fighter } \\
\text { - Narrator: " } 20^{\text {th }} \text { century fox and George Lucas, the man who } \\
\text { brought you American Graffiti, now bring you an adventure } \\
\text { unlike anything on your planet, Star Wars." (approaching Star } \\
\text { - Wars title getting closer with space background) }\end{array}$ \\
\hline Orientation & $\begin{array}{l}\text { - Leia and Chewbacca, Leia says "here they come" followed by } \\
\text { - } \text { attack by TIE fighters } \\
\text { - Nuke says, "they're coming in too fast!" } \\
\text { - Infamous Darth Vader torture scene with robot } \\
\text { - Narrator: "It's a big, sprawling space saga of rebellion and } \\
\text { romance." } \\
\text { - Laser battle featuring Han Solo running into Millennium } \\
\text { Falcon on Tattooine }\end{array}$ \\
\hline Complicating Action & $\begin{array}{l}\text { - Narrator: "It's a spectacle, light years ahead of its time" } \\
\text { - C3P0 and R2D2 introduction } \\
\text { - Bar fight with Obi-wan Kenobi \& light saber } \\
\text { - Narrator: "it's an epic of heroes..." } \\
\text { - Grappling hook scene, kiss between Luke and Leia } \\
\text { - Narrator: "and villains..." } \\
\text { - Darth Vader interrogating prisoners by killing them } \\
\text { - Narrator: "and aliens from a thousand worlds." }\end{array}$ \\
\hline Resolution & $\begin{array}{l}\text { - Major protagonists and antagonists placed in compromising } \\
\text { situations but are not resolved } \\
\text { - } \quad \text { Sand people scaring Luke scene } \\
\text { - } \text { Battle scene with Darth Vader + Obi-Wan Kenobi } \\
\text { - Interspersed action scenes (. storm troopers shooting, garbage } \\
\text { shoot scene, stealing R2D2 on Tattooine, alarms \& millennium }\end{array}$ \\
\hline
\end{tabular}




\begin{tabular}{|c|c|}
\hline Evaluation & $\begin{array}{l}\text { - "Star Wars, a billion years in the making, and it's coming to your } \\
\text { galaxy this summer." } \\
\text { Text places emphasis on the heroism and epic scope of the } \\
\text { science fiction journey. Traditional boy meets girl, good } \\
\text { versus evil dialogue established. (Ex. grappling hook } \\
\text { scene) } \\
\text { - Message reinforced by visuals interspersed throughout trailer, } \\
\text { particularly during the break up for the "it's an epic..." line } \\
\text { where major characters are established in very forward and } \\
\text { visually stimulating roles } \\
\text { - Narrator plays a critical role in trailer as an omniscient } \\
\text { personality, separate from the narrative }\end{array}$ \\
\hline Coda & $\begin{array}{l}\text { - Narrator, "Star Wars, a billion years in the making, and its } \\
\text { coming to your galaxy this summer." } \\
\text { - During narrator moments the Star Wars logo is approaching } \\
\text { screen with space background and explodes in last scene. } \\
\text { - Text on screen: "coming this summer from } 20^{\text {th }} \text { century fox" } \\
\text { with space background } \\
\text { - Fades to black }\end{array}$ \\
\hline
\end{tabular}

Star Wars, Episode I: The Phantom Menace (1999)

\begin{tabular}{|c|c|}
\hline Narrative Element & \multicolumn{1}{c|}{ Observations } \\
\hline Abstract & $\bullet \begin{array}{l}\text { 20th Century Fox and Lucas Film Ltd. logos role - not } \\
\text { necessarily the abstract but definite indicator of Star Wars } \\
\text { trailer }\end{array}$ \\
\hline $\begin{array}{l}5 \text { seconds of tanks rolling across green fields, goes to "sci-fi" } \\
\text { city setting on Naboo followed by female voice, "I will not } \\
\text { condone a course of action that will lead us to war." - scene } \\
\text { goes to face of woman in heavy makeup and garb }\end{array}$ \\
$\begin{array}{l}\text { Cue tanks and force shields, followed by man in same room of } \\
\text { action stating: "a communications disruption can only mean } \\
\text { one thing, invasion." } \\
\text { Draws attention to the narrative of the trailer }\end{array}$ \\
\hline
\end{tabular}




\begin{tabular}{|c|c|}
\hline Orientation & $\begin{array}{l}\text { - } \quad \text { Space ships landing on planet } \\
\text { - Darth Maul states to Emperor, "at last we will reveal ourselves } \\
\text { to the Jedi. At last we will have revenge." Interspersed with } \\
\text { invasion scenes (soldiers marching, dropping troops, etc.) } \\
\text { - Emperor in holograph, "begin landing your troops" } \\
\text { - Cuts to invading droids, running wildlife, etc. at invaders } \\
\text { - Establishes that Jedi vs. Sith at heart of invasion of unknown } \\
\text { - } \text { planet }\end{array}$ \\
\hline Complicating Action & $\begin{array}{l}\text { - } \quad \text { Empress, "The Federation has gone too far." More soldiers - cut } \\
\text { back to Empress councilor "The death toll is catastrophic." } \\
\text { - Empress: "Our people are dying senator, we must do something } \\
\text { quickly." } \\
\text { - Jedi, "there is something else behind all of this. They will kill } \\
\text { you if you stay, and I can only protect you, I can't fight a war } \\
\text { for you." } \\
\text { - What happened = Sith-backed invasion under the guise of } \\
\text { Trade Federation results in war between the Sith and Jedi. } \\
\text { - Random councilor, "I think we're going to have to accept } \\
\text { Trade Federation control for the time being." } \\
\text { - Security to Empress, "This is not a battle I think we can win." } \\
\text { - Empress: "I will sign no treaty Senator." } \\
\text { - Dialogue interspersed with action scenes: Jedi vs. robots, robots } \\
\text { taking human in similar garb as Empress hostage, ships that } \\
\text { look like robots fighting against ships that look like Jedi. } \\
\text { Establishes robots (and trade federation aliens) as evil and } \\
\text { Jedis/humans as good. } \\
\text { Empress: "I was not elected to watch my people die while you } \\
\text { discuss this invasion in a committee" to large group of } \\
\text { delegates; establishes her a leader or ruler of her people } \\
\text { Cue } 15 \text { seconds of pure action scenes - light sabers, laser } \\
\text { battles, resulting in space battle } \\
\text { Introduction of C3P0 and R2D2, "They will never get me onto } \\
\text { one of those ships." } \\
\text { Yoda seen, "always two there are; a master, and an } \\
\text { apprentice }\end{array}$ \\
\hline Resolution & $\begin{array}{l}\text { - Places major protagonists in comprising situations (Jedi and Sith } \\
\text { fighting in light-saber battle, space battles, etc.) } \\
\text { - More space and action scenes involving pod-racing, sea } \\
\text { monsters, space battles } \\
\text { - Light saber battle between Sith and Jedi from start }\end{array}$ \\
\hline
\end{tabular}




\begin{tabular}{|c|l|}
\hline Evaluation & $\begin{array}{l}\text { Overall, narrative structure is a little confusing - focus is on the } \\
\text { cinematic virtues of the film as opposed to the storyline } \\
\text { - }\end{array}$ \\
Clearly establishes the Sith vs. Jedi dichotomy as well as the \\
hero role for the Empress/female leader of the human planet \\
with phrases like "I will sign no treaty, senator." \\
- $\begin{array}{l}\text { Other than that, text is not particularly helpful. Introduces some } \\
\text { legacy characters like C3P0, R2D2, and Yoda but for purposes } \\
\text { of marketing the focus is on the Empress and the battles that } \\
\text { take place }\end{array}$ \\
\hline Coda & $\begin{array}{l}\text { Star Wars, Episode I: The Phantom Menace in iconic Star Wars } \\
\text { font after a pod-racing scene } \\
\text { Emperor in hologram, "wipe them out, all of them." } \\
\text { More clips (less than one second) with Jedi screaming "Noooo" } \\
\text { as the sound clip - clips include empress, droids, boy running } \\
\text { through a field" }\end{array}$ \\
\hline Cuts to credits followed by "The Saga Begins May 19th
\end{tabular}

Star Wars, Episode VII: The Force Awakens (2015)

\begin{tabular}{|c|c|}
\hline Narrative Element & Observations \\
\hline Abstract & $\begin{array}{l}\text { - } \quad \text { First shot abrupt, fully covered face in derelict technological } \\
\text { structure close up and then rapelling } \\
\text { - Female voice, "who are you?" } \\
\text { - Cut to same girl, walking with droid in desert. Rey: "I'm no } \\
\text { one." } \\
\text { - LucasFilm Ltd. comes across screen (34 seconds in) }\end{array}$ \\
\hline Orientation & $\begin{array}{l}\text { - Nazi-esque storm troopers scene, cuts to Finn and explosions in } \\
\text { space. Male voice, "I was raised to do one thing, but I've got } \\
\text { nothing to fight for." } \\
\text { - Crashes onto assumedly the same planet that Rey is on } \\
\text { - Kylo Ren, "Nothing will stand in our way" - watching red } \\
\text { beam out spaceship - close up, "I will finish what you started" } \\
\text { pans to Darth Vadar helmet destroyed on a shrine; torturing } \\
\text { human establishes him as antagonist } \\
\text { - Association is that Kylo Ren \& storm troopers on same team }\end{array}$ \\
\hline
\end{tabular}




\begin{tabular}{|c|c|}
\hline $\begin{array}{l}\text { Complicating } \\
\text { Action/Resolution }\end{array}$ & $\begin{array}{l}\text { - Millenium Falcon sweeping through battle scene on desert } \\
\text { planet. Establishes balance/opponent to storm troopers through } \\
\text { previous experience with film narrative } \\
\text { - Rey: "There are stories about what happened." } \\
\text { - Cuts to inside Millenium Falcon (easily recognizable) Han } \\
\text { Solo: "It's true, all of it." } \\
\text { - Cuts to iconic hyperspace space w/ Falcon } \\
\text { - Iconic TIE fighters and X-Wings in battle - sides are drawn } \\
\text { - Han: "The dark side, (scene with man being tortured and ex- } \\
\text { storm trooper getting ready for battle for rebellion) The Jedi, } \\
\text { (explosions, scenes on other planets), they're real (Luke face } \\
\text { covered \& R2D2)" } \\
\text { - Fight scenes, pans to Chewie and Holo as prisoners } \\
\text { - Female voice: "The Force., it's calling to you" as fight scenes } \\
\text { take place } \\
\text { - Kylo Ren \& Finn with light sabers about to fight, cut to black, } \\
\text { same female voice "just let it in." } \\
\text { - Harder to differentiate between narrative elements in this scene } \\
\text { - all are used but the its flow much more complex than I and II } \\
\text { - Narrative text suggests conflict and confusion in the plot - very } \\
\text { little is given away, characters are at odds with themselves while } \\
\text { participating in this bigger, iconic, rebel vs. empire struggle }\end{array}$ \\
\hline Evaluation & $\begin{array}{l}\text { - Star Wars: The Force Awakens fades into screen (big to small) } \\
\text { @ 2:05 mark and iconic music plays }\end{array}$ \\
\hline Coda & $\begin{array}{l}\text { - Cuts to same font with @ December } 18 \text { date YouTube video } \\
\text { cuts to more YouTube videos (teaser trailers, extras, etc.) for } \\
\text { last ten seconds of the trailer }\end{array}$ \\
\hline
\end{tabular}

\section{References}

Adams, W. J., \& Lubbers, C. A. (2000). Promotion of theatrical trailers. In S. T. Eastman (Ed.) Research in Media Promotion (pp. 231-261). New York, NY: Routledge.

Bordwell, D., \& Thompson, K. (2012). Film art: an introduction $\left(10^{\text {th }}\right.$ ed.) New York, NY: McGraw-Hill Education.

Bowen, J. (2005). Anticipation: the real life story of Star Wars: Episode I-The Phantom Menace. iUniverse Publications. 
Brown, S., Kozinets, R. V., \& Sherry, J. F. (2003). Teaching old brands new tricks: retro branding and the revival of branding meaning. Journal of Marketing, 67(3), 19-33.

Fabe, M. (2004). Closely watched films: an introduction to the art of narrative film technique. Berkeley: University of California press.

Finsterwalder, J., Kuppelwieser, V. G., \& de Villiers, M. (2012). The effects of film trailers on shaping consumer expectations in the entertainment industry - a qualitative analysis. Journal of Retailing and Consumer Services, 19, 589-595.

Genette, G. (1997). Paratexts: thresholds of interpretation. Cambridge, UK: Cambridge university press.

Gray, J. (2010). Show sold separately: promos, spoilers, and other media paratexts. New York, NY: New York university press.

Hamel, K. J. (2012). From advertisement to entertainment: early Hollywood film trailers. Quarterly Review of Film and Video, 29(2012), 268-278.

Hamel, K. J. (2012). Teaching with trailers: the pedagogical value of previews for introducing film analysis. Journal of Film and Video, 64(4), 38-49.

Higgins, S. (2008). Suspenseful situations: melodramatic narrative and the contemporary action film. Cinema Journal, 47(2), 74-96.

Jenkins, H. (2006). Convergence culture: where old and new media collide. New York, NY: New York university press.

Jerrick, D. (2013). The effectiveness of film trailers: evidence from the college student market. Journal of Undergraduate Research (XVI), 1-13.

Johnston, K. M. (2008). Coming soon: film trailers and the selling of Hollywood technology. 
Jefferson, NC: McFarland \& company.

Johnston, K. M. (2008). The coolest way to watch movie trailers in the world: trailers in the digital age. Convergence: the international journal of research into new media technologies, 14(2), 145-160.

Kernan, L. (2004). Coming attractions: reading American movie trailers. Austin, TX: University of Texas press.

Kerrigan, F. (2009). Film Marketing. New York, NY: Routledge.

Labov, W. (1973). Language in the inner city: studies in the black English vernacular. Philadelphia, PA: University of Pennsylvania press.

Labov, W. (1997). Some further steps in narrative analysis. The Journal of Narrative and Life History, 7, 395-415.

Labov, W. (2013). The language of life and death: a transformation of experience in oral narrative. Cambridge, UK: Cambridge university press.

Labov, W. \& Waletzky, J. (1967). Narrative analysis: oral versions of personal experience. In Helm, J (ed.) Essays on the verbal and visual arts. Seattle: University of Washington Press.

Langellier, K. M. (1989). Personal narratives: perspectives on theory and research. Text and Performance Quarterly, 9(4), 243-276.

Lubbers, C., \& Adams, W. J. (2004). Merchandising in the major motion picture industry: creating brand synergy and revenue streams. Journal of Promotion Management, 10(1/2), 55-63.

Maier, C. D. (2009). Visual evaluation in film trailers. Visual Communication, 8(2), 159-180.

Maier, C. D. (2011). Structure and function in the generic staging of film trailers. In R. Piazza, 
M. Bednarak, \& F. Rossi (Eds.) Pragmatics and beyond new series:

approaches to the fictional language of cinema and television. New York, NY: John Benjamins Publishing Company.

McFarlane, B. (1997). Novel to film: an introduction to the theory of adaptation. Oxford, UK: Clarendon press.

NewsWire, Canada. The Force Awakens around the world: Star Wars fans invited to join epic global event on YouTube. Canada NewsWire Press Release. Published on 26 Aug. 2015.

Pett, E. (2016). Stay disconnected: eventising Star Wars for transmedia audiences. Participations: Journal of Audience \& Reception Studies, 13(1), 152-169.

Street, S. (2009). Another medium entirely: Esther Harris, national screen service and film trailers in Britain, 1940-1960. Historical Journal of Film, Radio, and Television, 29(4), 433-448.

Sun Jensen, C. (2014). Reduced narration, intensified emotion: the film trailer, 8(1), 105-125. Taylor, C. (2015). How Star Wars conquered the universe: the past, present, and future of a multibillion dollar franchise. New York: NY: Basic Books.

Toolan, M. (2001). Narrative: a critical linguistic introduction ( $2^{\text {nd }}$ ed.). New York: Routledge. 